\title{
Endomembranes promote chromosome missegregation by ensheathing misaligned chromosomes
}

\author{
Nuria Ferrandiz ${ }^{1,2, \bowtie}$, Laura Downie ${ }^{1,3}$, Georgina P. Starling ${ }^{1,4,6}$, and Stephen J. Royle ${ }^{1,5, \bigotimes}$ \\ ${ }^{1}$ Centre for Mechanochemical Cell Biology, Warwick Medical School, Gibbet Hill Road, Coventry, CV4 7AL, UK; ${ }^{2}$ ORCiD: 0000-0002-7410-3470; ${ }^{3}$ ORCiD: \\ 0000-0001-9039-942X; ${ }^{4}$ ORCiD: 0000-0001-9485-8603; ${ }^{5} \mathrm{ORCiD:}$ 0000-0001-8927-6967; ${ }^{6}$ Present address: The Francis Crick Institute, London, NW1 1AT, UK
}

\begin{abstract}
Errors in mitosis that cause chromosome missegregation lead to aneuploidy and micronuclei formation which are associated with cancer. Accurate segregation requires the alignment of all chromosomes by the mitotic spindle at the metaphase plate, and any misalignment must be corrected before anaphase is triggered. The spindle is situated in a membrane-free "exclusion zone", beyond this zone, endomembranes (endoplasmic reticulum, nuclear envelope and other organelles) are densely packed. We asked what happens to misaligned chromosomes that find themselves beyond the exclusion zone? Here we show that such chromosomes become ensheathed in multiple layers of endomembranes. Chromosome ensheathing delays mitosis and increases the frequency of chromosome missegregation. The micronuclei that form following missegregation have a disrupted nuclear envelope with internal endomembranes. We use an induced organelle relocalization strategy in live cells to show that clearance of endomembranes allows for the rescue of chromosomes that were destined for missegregation. Our findings indicate that endomembranes promote the missegregation of misaligned chromosomes that are outside the exclusion zone, and therefore constitute a risk factor for aneuploidy.
\end{abstract}

chromosome missegregation | endoplasmic reticulum | mitotic spindle | chromosomal instability | cancer

Correspondence: n.ferrandiz@warwick.ac.uk or s.j.royle@warwick.ac.uk

\section{Introduction}

Accurate chromosome segregation during mitosis is essential to prevent aneuploidy, a cellular state of abnormal chromosome number (Duijf and Benezra, 2013). Errors in mitosis that lead to aneuploidy can occur via different mechanisms. These mechanisms include: mitotic spindle abnormalities (Ghadimi et al., 2000), incorrect kinetochore-microtubule attachments (Cimini et al., 2001), dysfunction of the spindle assembly checkpoint (Kalitsis et al., 2000), defects in cohesion (Daum et al., 2011) and failure of cytokinesis (Fujiwara et al., 2005). Some of these error mechanisms result in the missegregation of whole chromosomes, a process termed chromosomal instability (CIN). The majority of solid tumors are aneuploid, with higher rates of $\mathrm{CIN}$ and so understanding the mechanisms of chromosome missegregation is an important goal of cancer cell biology. In addition, chromosome missegregation is associated with micronuclei formation, which is linked to genomic rearrangements that may drive tumour progression (Crasta et al., 2012; Ly et al., 2017; Liu et al., 2018).

While the mitotic spindle has logically been the focus of efforts to understand chromosome missegregation, there has been less attention on other features of mitotic cells such as intracellular membranes. In eukaryotic cells, entry into mitosis constitutes a large scale reorganization of intracellular membranes. The nuclear envelope (NE) breaks down while the endoplasmic reticulum (ER) and Golgi apparatus disperse to varying extents (Hepler and Wolniak, 1984; Warren, 1993). These organelle remnants - collectively termed "endomembranes" - are localized toward the cell periphery while the mitotic spindle itself is situated in an "exclusion zone" which is largely free of membranes and organelles (Bajer, 1957; Porter and Machado, 1960; Nixon et al., 2017). The endomembranes beyond the exclusion zone are densely packed although the details of their ultrastructure varies between cell lines (Puhka et al., 2007; Lu et al., 2009, 2011; Puhka et al., 2012; Champion et al., 2017). This arrangement means that, although mitosis is open in mammalian cells, the spindle operates within a partially closed system. Several lines of evidence suggest that endomembranes must be cleared from the exclusion zone in order for the mitotic spindle to function normally (Vedrenne et al., 2005; Schlaitz et al., 2013; Champion et al., 2019; Kumar et al., 2019; Merta et al., 2021). In addition, it is thought that this arrangement is required to concentrate factors needed for spindle formation (Schweizer et al., 2015).

This study was prompted by a simple question: what happens to misaligned chromosomes that find themselves beyond the exclusion zone? We show that such chromosomes become ensheathed in multiple layers of endomembranes. Chromosome ensheathing delays mitosis and increases the frequency of chromosome missegregation and subsequent micronuclei formation. Using an induced organelle relocalization strategy we demonstrate that clearance of endomembranes allows the rescue of chromosomes that were destined for missegregation. Our findings indicate that endomembranes are a risk factor for $\mathrm{CIN}$ if the misaligned chromosomes go beyond the exclusion zone boundary during mitosis.

\section{Results}

Misaligned chromosomes outside the exclusion zone are ensheathed in endomembranes. During mitosis, the spindle apparatus is situated in a membrane-free "exclusion zone". Outside the exclusion zone, the ER and nuclear envelope collectively called "endomembranes" - surround the mitotic spindle. We investigated the organization of endomembranes in mitotic cells using light and electron microscopy. First, we carried out live-cell imaging of mitotic RPE-1 cells that stably co-express GFP-Sec61 $\beta$ and Histone H3.2-mCherry, stained with SiR-tubulin to mark the ER, DNA and microtubules, respectively. These images revealed a mitotic spindle-sized exclusion zone from which GFP-Sec16 $\beta$ signal was absent (Figure 1A). Second, serial block face-scanning electron microscopy (SBF-SEM) of mitotic RPE-1 cells showed that the ellipsoid exclusion zone is largely devoid of endomembranes, 
bioRxiv preprint doi: https://doi.org/10.1101/2021.04.23.441091; this version posted September 2, 2021. The copyright holder for this preprint (which was not certified by peer review) is the author/funder, who has granted bioRxiv a license to display the preprint in perpetuity. It is made available under aCC-BY-NC 4.0 International license.
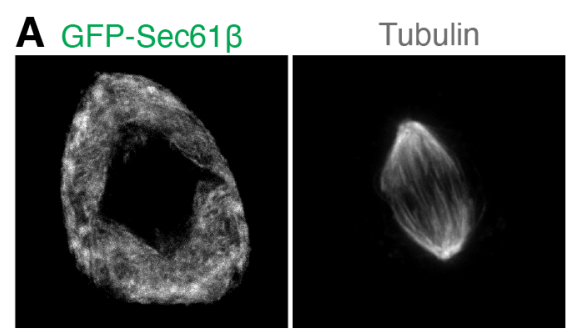

C DNA + GFP-Sec61ß
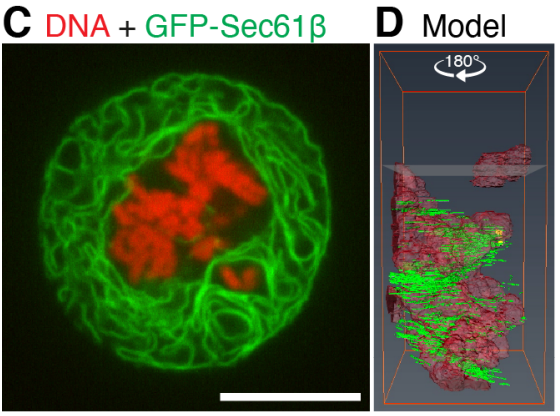
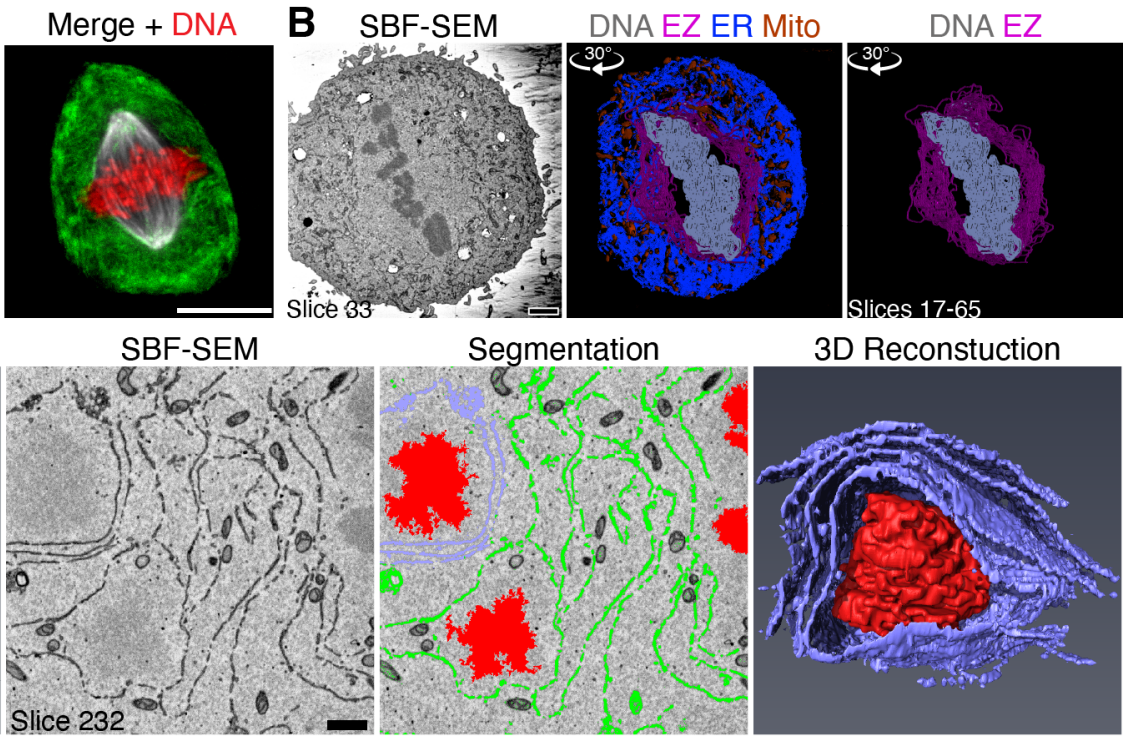

Figure 1. Misaligned chromosomes outside the exclusion zone are ensheathed in endomembranes

(A) Confocal image of a mitotic RPE-1 cell stably co-expressing GFP-Sec61ß (green) Histone H3.2-mCherry (DNA, red) and stained with SiR-Tubulin (gray). Scale bar, $10 \mu \mathrm{m}$. (B) Serial block face-scanning electron microscopy (SBF-SEM) imaging of mitotic cells and subsequent segmentation reveals the endomembranes (ER, blue) and mitochondria (Mito, orange) are beyond the exclusion zone boundary (EZ, pink), with the chromosomes (DNA, gray) within. Angle of rotation about $Y$ axis is shown. Scale bar, $2 \mu \mathrm{m}$. (C) Confocal image of an untreated HeLa cell co-expressing Histone H2B-mCherry and GFP-Sec61 $\beta$ with a spontaneously occurring ensheathed chromosome. (D) SBF-SEM imaging of an untreated HeLa cell with a spontaneously occurring ensheathed chromosome. Model shows the position of two ensheathed chromosomes (red) away from the metaphase plate, height of slice 232 is indicated. Segmentation shows endomembranes (green and lilac surrounding the upper chromosome), rendered in 3D (Reconstruction). Scale bar, $1 \mu \mathrm{m}$. See Supplementary Videos SV1 and SV2.

including mitochondria and other organelles. Outside the exclusion zone, endomembranes are tightly packed and the border between these two regions is clearly delineated and could be segmented (Figure 1B).

Misaligned chromosomes are those that fail to attach, or lose their attachment to the mitotic spindle. What happens to misaligned chromosomes that find themselves amongst the endomembranes beyond the exclusion zone? HeLa cells have high rates of chromosome misalignment and live cell imaging showed that misaligned chromosomes could be situated beyond the exclusion zone (Figure 1C). Reconstruction of SBF-SEM data from HeLa cells showed that three to four layers of endomembranes "ensheath" the chromosomes beyond the exclusion zone (Figure 1D and Supplementary Video SV1 and SV2). We use the term "ensheathed" to describe how these chromosomes are surrounded by endomembranes but not fully enclosed in any one layer as though in a vesicle.

In order to study chromosome ensheathing in diploid cell lines, we needed to artificially increase the frequency of misaligned chromosomes in mitosis. Our main model was RPE-1 cells pre-treated with $150 \mathrm{nM}$ GSK923295, a CENP-E inhibitor (Wood et al., 2010), before washing out the drug for $1 \mathrm{~h}$ (Figure 2A). In parallel, we also used a system of targeted Y-chromosome spindle detachment in DLD-1 cells (Ly et al., 2017) (Figure S1). Using live-cell imaging in both cell types, we observed that misaligned chromosomes beyond the exclusion zone are submerged in endomembranes (Figure $2 B$ and S1D). Next, we used an image analysis method to determine the location of kinetochores in 3D space and map these positions relative to the exclusion zone boundary (see Methods, Figure 2D and S1E). Kinetochores of chromosomes that were not aligned at the metaphase plate therefore fell into two categories: those that were surrounded by GFP-Sec61 $\beta$ signal, termed 'ensheathed' and those that were not, termed 'free' (Figure 2B,D).
Spatial analysis revealed that the kinetochores of ensheathed chromosomes were beyond the exclusion zone, whereas kinetochores of free chromosomes lay at the boundary in RPE-1 cells (Figure 2E). In DLD-1 cells the distinction was even more clear, with the kinetochores of free chromosomes positioned inside the exclusion zone S1F). The exclusion zone therefore approximately defines chromosome misalignment, with those chromosomes beyond the exclusion zone likely to be ensheathed by endomembranes. However, imaging GFP-Sec61 $\beta$ was required to verify that a chromosome was fully ensheathed.

We again used SBF-SEM to observe how chromosomes beyond the exclusion zone interact with endomembranes in RPE-1 cells. Cells observed by fluorescence microscopy to have at least one ensheathed chromosome were selected for 3D EM analysis (Figure 2E). Segmentation of these datasets confirmed that the chromosome was fully beyond the exclusion zone boundary (Figure $2 \mathrm{~F}$ and Supplementary Video SV3) and was ensheathed in several layers of endomembranes (Figure 2E).

The observation of ensheathed chromosomes raised immediate questions about their fate and whether ensheathing leads to aberrant mitosis.

\section{Ensheathed chromosomes promote micronuclei} formation. To determine the impact of ensheathed chromosomes on cell division, we first analyzed mitotic progression in RPE-1 cells stably expressing GFP-Sec61 $\beta$ with induction of ensheathed chromosomes using GSK923295 pre-treatment. Cells that had at least one ensheathed chromosome showed prolonged mitosis; median nuclear envelope breakdown (NEB)-to-anaphase timing of $66 \mathrm{~min}$ compared with $27 \mathrm{~min}$ in GSK923295 pre-treated cells where all chromosomes were aligned. The time to align the majority of chromosomes (NEB-to-metaphase) was delayed for cells with either a free or an ensheathed 
bioRxiv preprint doi: https://doi.org/10.1101/2021.04.23.441091; this version posted September 2, 2021. The copyright holder for this preprint (which was not certified by peer review) is the author/funder, who has granted bioRxiv a license to display the preprint in perpetuity. It is made available under aCC-BY-NC 4.0 International license.

A

\begin{tabular}{|c|c|c|}
\hline GSK923295 $150 \mathrm{nM}$ & Washout & Analysis \\
\hline
\end{tabular}

C

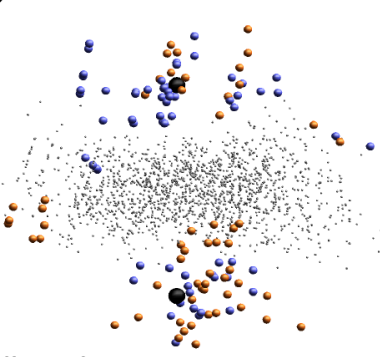

Aligned

Free

Ensheathed

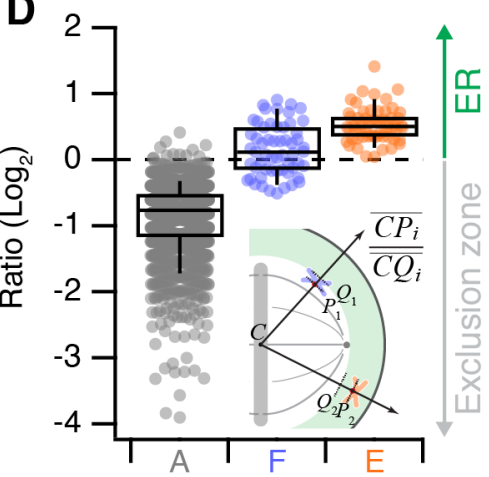

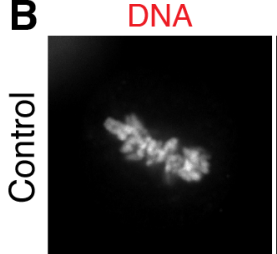

GFP-Sec61ß
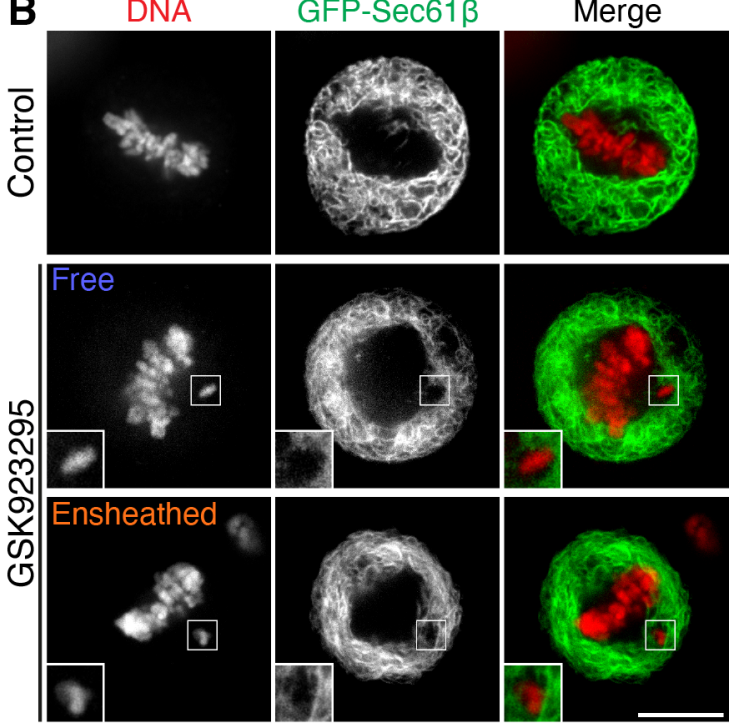

E SBF-SEM zoom $\quad$ DNA ER Mito
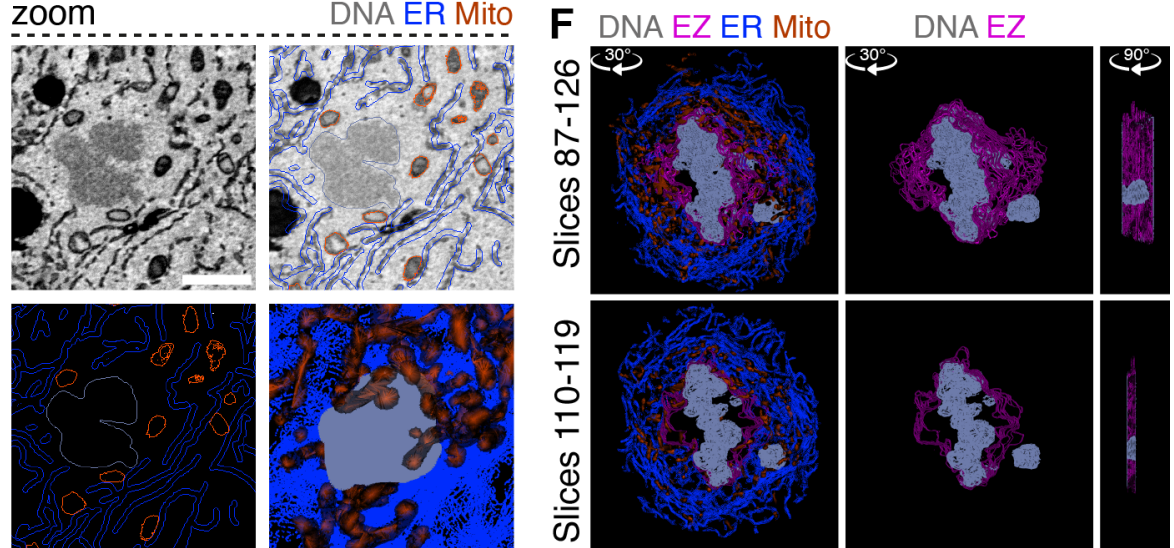

Figure 2. Induction of misaligned chromosomes in stably diploid RPE1 cells by pre-treatment with a CENP-E inhibitor

(A) Polar, misaligned chromosomes can be induced by treatment with CENP-E inhibitor GSK923295 (150 nM, $3 \mathrm{~h}$ ) and subsequent washout (1 h). (B) Confocal micrographs to show that these misaligned chromosomes (SiR-DNA, red) are either outside the exclusion zone delineated by GFP-Sec61 $\beta$ (green), termed Ensheathed or at the boundary and inside the exclusion zone, termed Free. Scale bar, $10 \mu \mathrm{m}$. (C) Spatially averaged 3D view of all CENP-C-positive kinetochores in the dataset (see Methods). Small gray points represent kinetochores at the metaphase plate. Colored points represent misaligned chromosomes that were ensheathed (orange) and those that were not (Free, blue). Spindle poles are shown in black. (D) Box plot to show the relative position of each kinetochore relative to the exclusion zone boundary. Chromosome misalignment was induced pre-treatment with GSK923295 (150 nM). Ratio of kinetochores within the exclusion zone are $<0$ and those within the ER are $>0$ on a log2 scale. Dots represent kinetochore ratios from 31 RPE-1 cells at metaphase. Boxes show IQR, bar represents the median and whiskers show 9th and 91st percentiles. Inset: Schematic diagram to show how the position of kinetochores relative to the exclusion zone boundary was calculated. $\mathrm{C}$ is the centroid of aligned kinetochores, $\mathrm{P}$ is a kinetochore and $\mathrm{Q}$ is the point along the 3D path (CP) that intersects the exclusion zone boundary. The ratio of $C P$ to $C Q$ is taken for each kinetochore (aligned kinetochores, gray; free, blue; and ensheathed, orange). (E) Single SBF-SEM image showing an ensheathed chromosome. Boxed region is shown expanded and modeled (zoom). Scale bar, $2 \mu \mathrm{m}$ (black) and $500 \mathrm{~nm}$ (white). (F) Modeled substacks from SBF-SEM images showing a chromosome outside the exclusion zone, ensheathed in ER. Slices shown and angles and axes of rotation are indicated (See Supplementary Videos SV3).

chromosome, but cells with an ensheathed chromosome had an additional delay to progress to anaphase (Figure $3 A)$. Given these delays, we next confirmed that the spindle assembly checkpoint was active in these cells. The amount of Mad2 and Bub1 detected by immunofluorescence at CENP-C positive kinetochores of free or ensheathed chromosomes was similar, and four-fold higher than at kinetochores of aligned chromosomes (Figure 3B,C and S2A,B, for DLD-1 cells).

To understand the fate of cells with an ensheathed chromosome, we next examined mitosis in control or GSK923295-pre-treated RPE-1 cells stably expressing GFP-Sec61 $\beta$ using live-cell spinning disc microscopy (Figure 3D). In cells with an ensheathed chromosome, we observed the long delay in mitosis relative to control cells, and that mitosis was often resolved by missegregation and formation of a micronucleus (Figure 3D and S2C for DLD-1 cells). These experiments suggested that ensheathed chromosomes are potentially a precursor to micronuclei. We therefore followed the fate of mitotic cells by long-term live-cell imaging in order to understand the likelihood of mitotic outcomes. Our sample of cells pre-treated with GSK923295 included the three metaphase classes: aligned (25.8\%), free (5.4\%), and ensheathed $(65.6 \%)$. The most frequent fate of cells with an ensheathed chromosome was micronucleus formation (39\%). Of the 47 cells that formed a micronucleus after division in the dataset, 46 were from the ensheathed class (Figure 3E). This promotion of micronucleus formation was significant in cells with an ensheathed chromosome compared to free $(p=$ $1.3 \times 10^{-3}$, Fisher's exact test). A smaller proportion of cells with an ensheathed chromosome exited mitosis normally, albeit with a delay (34\%), with the remainder showing other defects or death $(20 \%$ or $8 \%)$. Cells pre-treated with GSK923295, that had aligned all their chromosomes, had 
bioRxiv preprint doi: https://doi.org/10.1101/2021.04.23.441091; this version posted September 2, 2021. The copyright holder for this preprint (which was not certified by peer review) is the author/funder, who has granted bioRxiv a license to display the preprint in perpetuity. It is made available under aCC-BY-NC 4.0 International license.

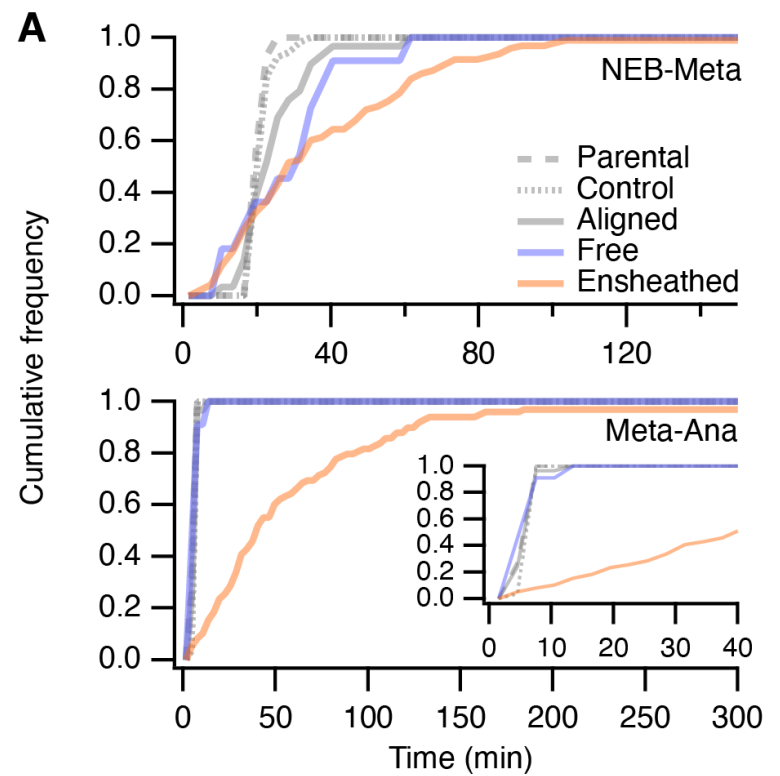

D
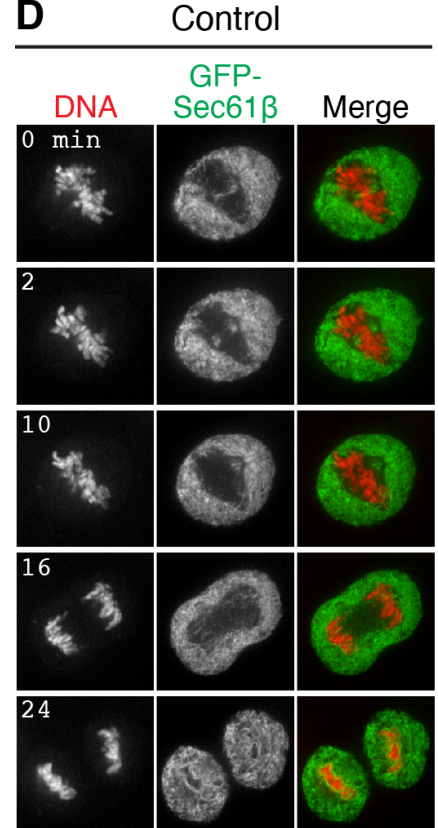
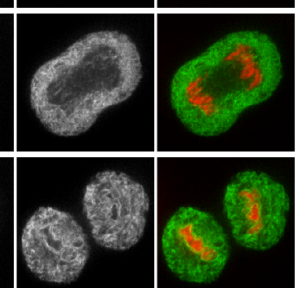

GSK923295
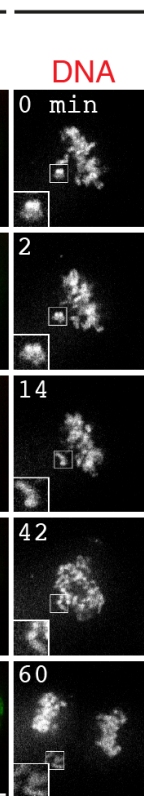

B

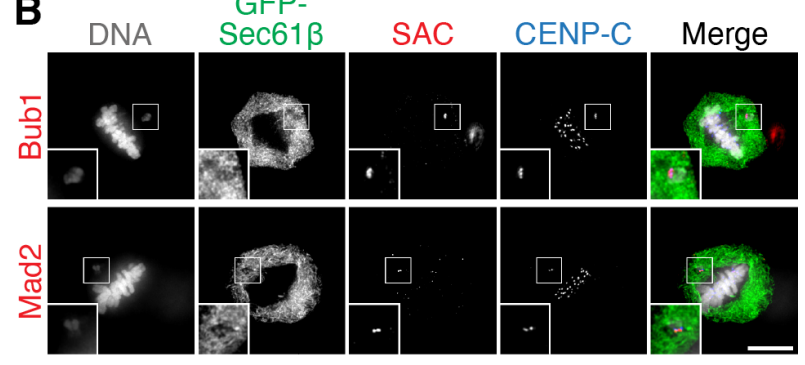

C
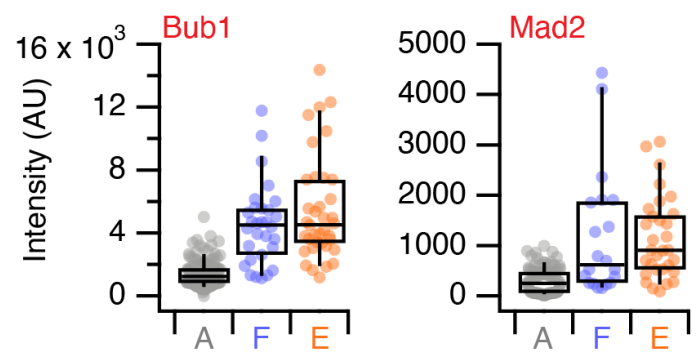

E Class

Fate
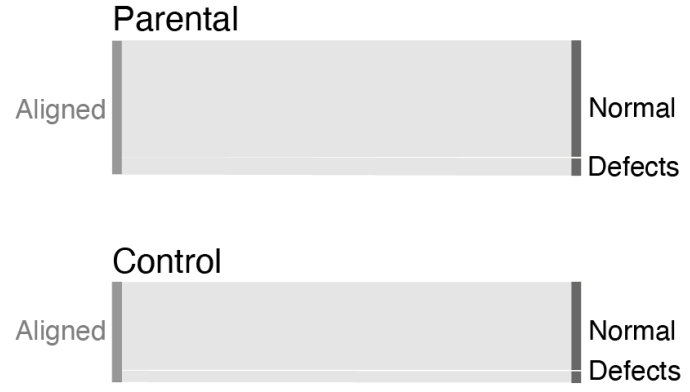

\section{GSK923295}

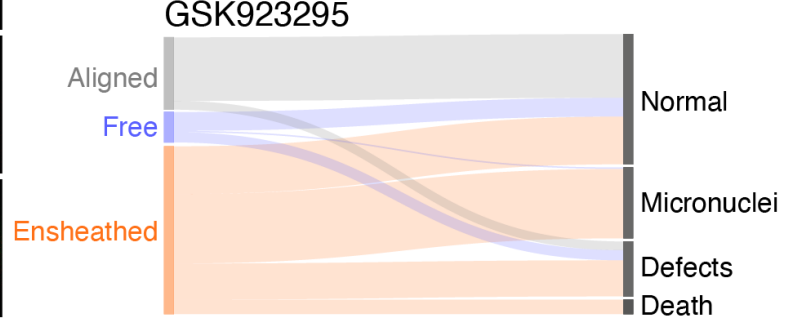

Figure 3. Impact of ensheathed chromosomes on cell division.

(A) Mitotic timing of RPE-1 cells. Cumulative frequencies for nuclear envelope breakdown to metaphase (NEB-Meta) and metaphase to anaphase (Meta-Ana) are shown. RPE-1 stably expressing GFP-Sec61 $\beta$ were treated with $150 \mathrm{nM}$ GSK923295 for $3 \mathrm{~h}$ before washout. Three classes of metaphase were seen: all chromosomes aligned (Aligned, $n=29$ ), cells with one or more free chromosome (Free, $n=11$ ), and cells with one or more ensheathed chromosome (Ensheathed, $n=107$ ). Timing of untreated parental (Parental, $n=69$ ) and stable RPE-1 (Control, $n=52$ ) cells is also shown. Inset in Meta-Ana shows same data on an expanded timescale. Comparison of NEB-Meta and Meta-Ana timing distributions for Ensheathed vs Control, $\mathrm{p}=1.9 \times 10^{-57}$ and $7.8 \times 10^{-23}$, Kolmogorov-Smirnov test. (B) Micrographs of immunofluorescence experiments to detect Bub1 or Mad2 (SAC, red) at kinetochores (CENP-C, blue) in cells stably expressing GFP-Sec61 $\beta$ (green), DAPI-stained DNA is shown in gray. Scale bar, $10 \mu \mathrm{m}$. (C) Quantification of Bub1 and Mad2 immunofluorescence at kinetochores marked by CENP-C. Ensheathed chromosomes were classified using the GFP-Sec61 $\beta$ signal. Dots represent cells, boxes show IQR, bar represents the median and whiskers show 9th and 91 st percentiles. (D) Stills from live cell imaging experiments to track the fate of ensheathed chromosomes. A control or GSK923295-pre-treated GFP-Sec61 $\beta$ RPE-1 cell is shown, DNA is stained using SiR-DNA (red). Scale bar, $10 \mu \mathrm{m}$. Shown in Supplementary Videos SV4 and SV5. (E) Sankey diagram to show the fate (right) of cells in each of the three metaphase classes (left). Fates include normal division, micronuclei formation, death and other defects (lagging chromosome, cytokinesis failure). Note that the fate of cells (and not chromosomes) is tracked. A cell with three misaligned chromosomes, only one of which is ensheathed is classified as Ensheathed. Parental RPE-1 cells (Parental, $n=92$ ) and untreated RPE-1 stably expressing GFP-Sec61 $\beta$ (Control, $n=69$ ) are from two and three independent overnight experiments, respectively. Fates of GSK923295-pre-treated GFP-Sec61 $\beta$ cells $(n=186)$ were compiled from seven experiments. Fates of individual chromosomes are shown in Supplementary Figure S3B) 
bioRxiv preprint doi: https://doi.org/10.1101/2021.04.23.441091; this version posted September 2, 2021. The copyright holder for this preprint (which was not certified by peer review) is the author/funder, who has granted bioRxiv a license to display the preprint in perpetuity. It is made available under aCC-BY-NC 4.0 International license.

similar fates to parental and control cells (Figure 3E and Supplementary Video SV4 and SV5). These fate-mapping experiments suggest that ensheathing of chromosomes by endomembranes promotes the formation of micronuclei.

\section{Micronuclei formed from ensheathed chromosomes have} a disrupted nuclear envelope. Micronuclei can undergo a collapse of their nuclear envelope which manifests as ER tubules invading the micronuclear space (Hatch et al., 2013). We therefore asked if micronuclei that formed from ensheathed chromosomes were similarly defective. Using confocal imaging of RPE-1 cells stably co-expressing GFP-Sec61 $\beta$ and either mCherry-BAF or LBR-mCherry that were fixed $8 \mathrm{~h}$ after washout of GSK923295 to examine micronucleus integrity, we found the majority of micronuclei have ER inside the micronucleus (Figure 4). The fluorescence of GFP-Sec61 $\beta$ was higher at the micronucleus when compared with the main nucleus (Figure 4B). Moreover, the levels of either mCherry-BAF or LBR-mCherry were correlated with GFP-Sec61 $\beta$. To confirm that these micronuclei had disrupted nuclear envelopes, we stained for H3K27Ac, a modification to Histone $\mathrm{H} 3$ that is removed by exposure to the cytoplasm (Mammel et al., 2021). Intact micronuclei had similar H3K27Ac signals to the corresponding main nucleus, whereas in micronuclei that were disrupted, the signal was lost (Figure 4A). The ratio of H3K27Ac signal at the micronucleus compared with the main nucleus was anticorrelated with the ratios of GFP-Sec61 $\beta$, mCherry-BAF, and LBR-mCherry (Figure 4B). Since the majority of micronuclei formed following pre-treatment of RPE-1 cells with GSK923295 are derived from ensheathed chromosomes (Figure 3E), these data suggest that the ensheathing process may contribute to the formation of defective micronuclear envelope.

Alternatively, the initial recruitment of nuclear envelope to the nascent micronucleus may be defective. Indeed a previous report suggested that the position of the chromosome which develops into a micronucleus can influence its ability to recruit nuclear envelope (Liu et al., 2018). We therefore investigated the initial recruitment of nuclear envelope to ensheathed chromosomes, and compared it with recruitment to lagging chromosomes (chromosomes stranded in the spindle midzone during anaphase) (Supplementary Figure S4). Recruitment of these two proteins could be tracked, along with Sec61 $\beta$, at nuclear structures using automated methods and plotted relative to anaphase onset. On average, the time-to-peak recruitment of BAF and LBR was similar for ensheathed and lagging chromosomes and in either case was equivalent to the recruitment of each protein to the main nuclear mass (Supplementary Figure S4). At lagging chromosomes, the time-to-peak recruitment (mean \pm SD) of mCherry-BAF was $6.3 \pm 0.9 \mathrm{~min}$ and for LBR-mCherry $11.5 \pm 5.5 \mathrm{~min}$, similar to that measured at the main mass $(7.8 \pm 1.5 \mathrm{~min}$ and $9.5 \pm 1.2 \mathrm{~min}$, respectively). The time-to-peak recruitment at ensheathed chromosomes for mCherry-BAF was $5.8 \pm 1.5 \mathrm{~min}$ and for LBR-mCherry, $9.5 \pm 6.3 \mathrm{~min}$, similarly showing comparable kinetics to the main mass $(9.0 \pm 1.3$ and $10.6 \pm 2.5 \mathrm{~min}$, respectively). In each cell line, dynamics of GFP-Sec61 $\beta$ recruitment to lagging chromosomes and the main nuclear mass were also equivalent (cell line expressing mCherry-BAF $9.9 \pm 2.8$ and $10.5 \pm 1.6 \mathrm{~min}$ or LBR-mCherry $14.0 \pm 4.9$ and $10.5 \pm 2.5 \mathrm{~min}$, chromosome and main mass respectively) and similarly to ensheathed chromosomes and the main mass (cell line expressing mCherry-BAF $8.3 \pm 3.4 \mathrm{~min}$ and $10.3 \pm 1.5 \mathrm{~min}$ or
LBR-mCherry $10.1 \pm 6.6 \mathrm{~min}$ and $9.0 \pm 3.8 \mathrm{~min}$, chromosome and main mass respectively). These data suggest that the position of chromosomes which develop into micronuclei has negligible influence on the initial recruitment phase of nuclear envelope formation.

Together these results indicate that while NE reformation at micronuclei that form from ensheathed chromosomes proceeds normally, it promotes the formation of micronuclear envelopes whose integrity is disrupted.

Kinetochores of ensheathed chromosomes fail to make end-on microtubule attachments. We hypothesized that ensheathed chromosomes become missegregated due to the inability of microtubules to negotiate several layers of endomembranes. We examined microtubule-kinetochore attachments using immunofluorescence and found no end-on attachments at ensheathed chromosomes (Figure 5A). Instead, in some cells, we observed MTs passing by one or both kinetochores of ensheathed chromosomes, suggesting potential lateral attachments to the side of MTs may be possible (single, $23.8 \%$; both, $76.2 \%$, Figure $5 \mathrm{~A}$ ). However, at this resolution we could not determine whether kinetochores are contacted or if a layer of endomembrane prevents this. We confirmed that ensheathed chromosomes have no stable end-on kinetochore-microtubule attachments by detecting localization of kinastrin, a marker for stable end-on attachment (Dunsch et al., 2011). GFP-Sec61 $\beta$ RPE-1 cells pre-treated with GSK923295 were co-stained for kinastrin and CENP-C (Figure 5B,C). Automated detection of kinastrin and CENP-C colocalization revealed that $26.8 \%$ of kinetochores that were aligned had kinastrin signal. In contrast, colocalization of kinastrin with kinetochores of free or ensheathed chromosomes was no greater than chance (Figure $5 \mathrm{C}$ ). These data suggest that ensheathed chromosomes have the potential to form lateral contact with MTs but any contacts do not become end-on microtubule attachments.

It is not possible to tell from fixed-cell experiments if lateral MT contacts are sufficient for chromosome rescue. To address this question we used live-cell imaging to monitor chromosome, ER and microtubule behaviors in mitotic cells that have ensheathed chromosomes. RPE-1 cells stably co-expressing Histone H3.2-mCherry and GFP-Sec61 $\beta$ were stained with SiR-Tubulin and imaged by confocal microscopy. We observed that free chromosomes that had microtubule contacts could be rescued and aligned at the metaphase plate albeit after a delay (Figure $5 \mathrm{D}$ and Supplementary Video SV6). By contrast, ensheathed chromosomes that resulted in micronuclei had no detectable microtubule contacts (Figure 5E and Supplementary Video SV7). These experiments suggest that there are two possible mechanisms by which endomembranes could promote miseggregation and micronuclei formation. First, endomembranes may impair (but not prevent) contact between spindle microtubules and ensheathed kinetochores. Second, if ensheathed chromosomes are able to attach to the spindle their movement is impeded by endomembranes.

Induced relocalization of ER enables the rescue of ensheathed chromosomes. Does ensheathing of misaligned chromosomes cause chromosome missegregation? To answer this question we sought a way to clear the mitotic ER and test if this enabled subsequent rescue of misaligned chromosomes to the metaphase plate. To clear the 
bioRxiv preprint doi: https://doi.org/10.1101/2021.04.23.441091; this version posted September 2, 2021. The copyright holder for this preprint (which was not certified by peer review) is the author/funder, who has granted bioRxiv a license to display the preprint in perpetuity. It is made available under aCC-BY-NC 4.0 International license.
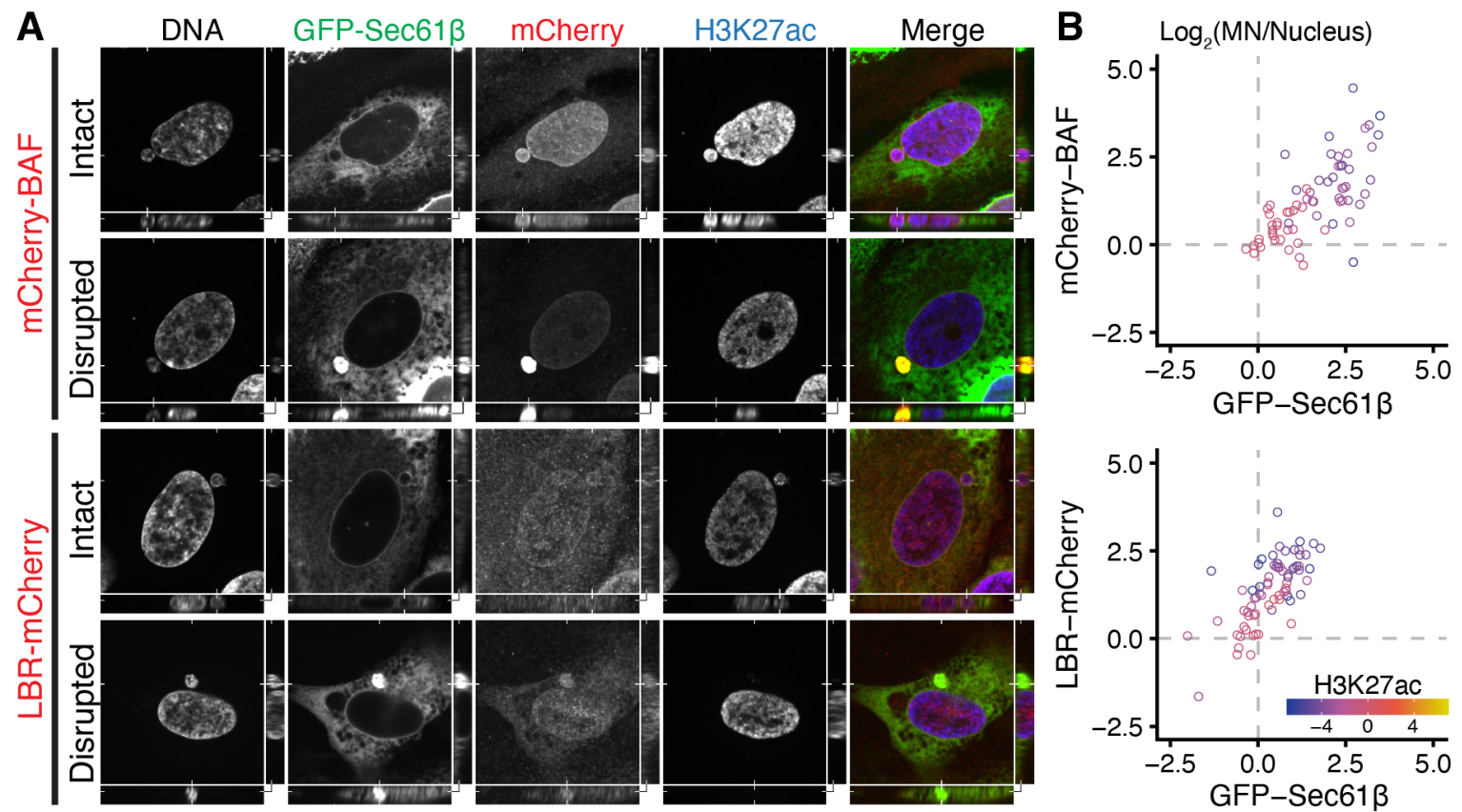

Figure 4. Missegregation of an ensheathed chromosome results in a micronucleus with a disrupted nuclear envelope.

(A) Example confocal images showing examples of intact or disrupted micronuclei as indicated. Images show mCherry-BAF or LBR-mCherry (red) stably co-expressed with GFP-Sec61 $\beta$ (green) in RPE-1 cells, H3K27Ac was detected by immunofluorescence (blue), and DNA stained with DAPI. XY view is through the centre of the micronucleus, $Y Z$ (right) and $X Z$ (below) are orthogonal views at the positions indicated. (B) Fluorescence intensity of mCherry-BAF or LBR-mCherry as a function of GFP-Sec61 $\beta$ intensity. Intensity of H3K27Ac is indicated using the colorscale. Data are plotted as the log2 ratio of intensity at the micronucleus versus main nucleus. For RPE1 GFP-Sec61 $\beta$ mCherry-BAF $n=71$ cells and LBR-mCherry $n=73$ cells, from 3 independent experiments in each cell type.

mitotic ER, we used an induced relocalization strategy (Figure 6A). Induced relocalization of small organelles has been demonstrated for Golgi, intracellular nanovesicles and endosomes, typically using heterodimerization of FKBP-rapamycin-FRB with the FKBP domain fused to the organelle and the FRB domain at the mitochondria (Dunlop et al., 2017; Hirst et al., 2015; Larocque et al., 2020; van Bergeijk et al., 2015). We reasoned that a large organellar network, such as the ER, may be cleared by inducing its relocalization to the cell boundary. Our strategy therefore comprised an ER-resident hook (FKBP-GFP-Sec61 $\beta$ ) and a plasma membrane anchor (stargazin-mCherry-FRB) with application of rapamycin predicted to induce the relocalization of ER to the plasma membrane (Figure 6A). HCT116 cells were used for these experiments as they are near diploid, easy to transfect, and showed a similar fate and mitotic response to GSK923925 pre-treatment as RPE-1 (Supplementary Figure S5).

We found that the clearance of ER in mitotic cells with this strategy was efficient, occurring in $89.2 \%$ of HCT116 cells expressing the system after treatment with $200 \mathrm{~nm}$ rapamycin. Onset was variable with a median time to maximum clearance of $15 \mathrm{~min}$ (IQR, $12 \mathrm{~min}$ to $24 \mathrm{~min}$, Figure $6 \mathrm{~B})$. Importantly, induced relocalization of FKBP-GFP-Sec61 $\beta$ to the plasma membrane represented the clearance of $E R$ and not the extraction of the protein since immunostaining of two other ER resident proteins KDEL and calnexin also showed relocalization to the plasma membrane (Figure $6 \mathrm{C}$ ).

We next tested whether ER clearance could be used as an intervention in cells with ensheathed chromosomes. To do this, HCT116 cells expressing FKBP-GFP-Sec61 $\beta$ and stargazin-mCherry-FRB, pre-treated with $150 \mathrm{nM}$ GSK923295 to induce ensheathed chromosomes, were imaged as $200 \mathrm{nM}$ rapamycin was applied to induce clearance of the ER. In control cells where no rapamycin was applied, the cells were arrested in mitosis for prolonged periods. In cells where the ER had been cleared, congression of the ensheathed chromosome was clearly seen after clearance had occurred (Figure 6D and Supplementary Video SV8). We used automated image analysis to track the $3 \mathrm{D}$ position of the misaligned chromosome over time, in an unbiased manner (Figure 6E-F). Congression of the ensheathed chromosome within 80 min was seen in $86.7 \%$ of cells with induced ER clearance. In control cells the majority $(66.7 \%)$ were unable to resolve the ensheathed chromosome in the same time (Figure $6 \mathrm{D}-\mathrm{F})$. These data suggest that ER clearance is an effective intervention in cells with ensheathed chromosomes and points to a causal role for endomembranes in chromosome missegregation.

\section{Discussion}

This study demonstrates that misaligned chromosomes located beyond the exclusion zone are liable to become ensheathed by endomembranes. The fate of cells with ensheathed chromosomes is biased towards missegregation, aneuploidy and micronuclei formation. We showed that if the ER was cleared from live mitotic cells, these chromosomes could be rescued by the mitotic spindle, an intervention which suggests that chromosome ensheathing by endomembranes is a risk factor for chromosome missegregation and subsequent aneuploidy.

Chromosomes can become misaligned during mitosis for a number of reasons, but we show here that those that transit out of the exclusion zone become ensheathed in endomembranes. We demonstrated this with four different cell models: RPE-1 or HCT116 cells pre-treated with a CENP-E inhibitor, DLD-1 cells with targeted disconnection of the Y-chromosome and HeLa cells with spontaneously arising misaligned chromosomes. In each case misaligned 
bioRxiv preprint doi: https://doi.org/10.1101/2021.04.23.441091; this version posted September 2, 2021. The copyright holder for this preprint (which was not certified by peer review) is the author/funder, who has granted bioRxiv a license to display the preprint in perpetuity. It is made available under aCC-BY-NC 4.0 International license.
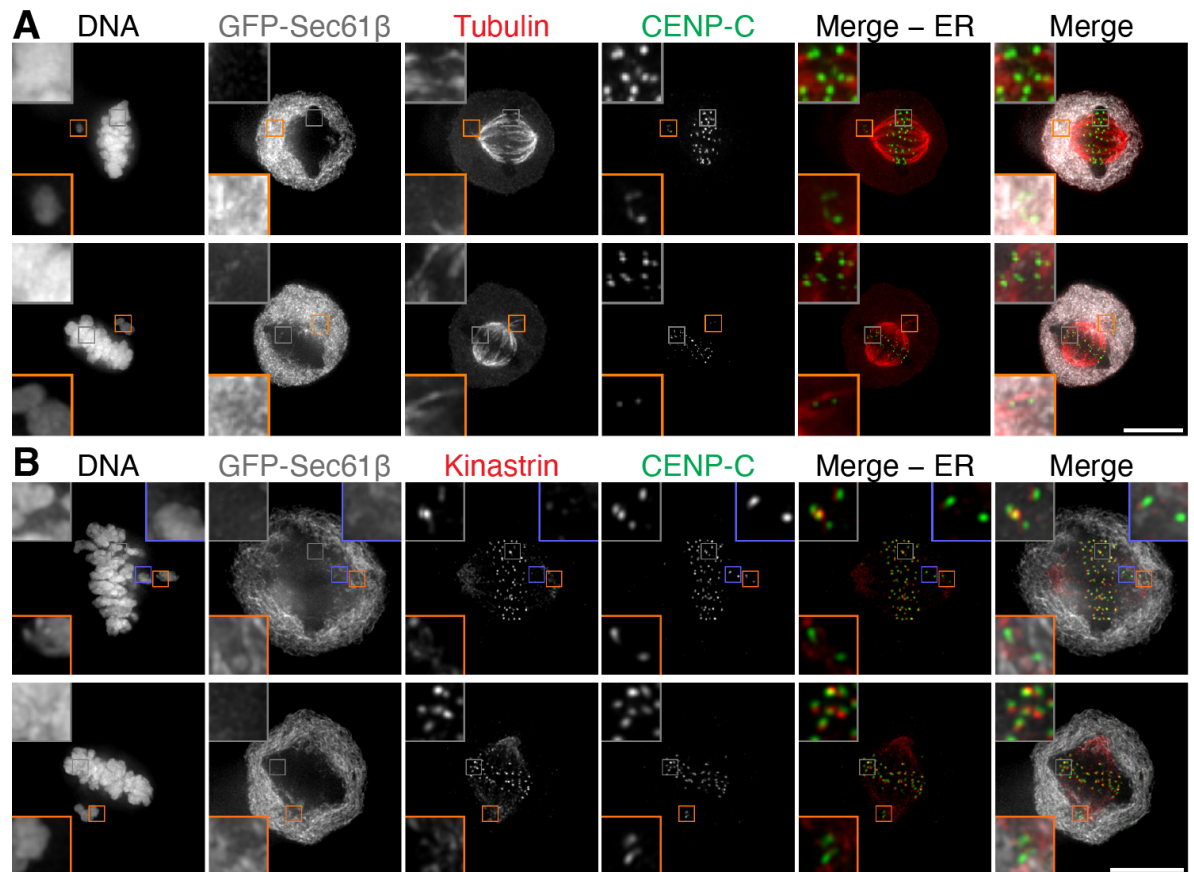

GFP-Sec61ß

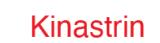

CENP-C

Merge - ER

Merge
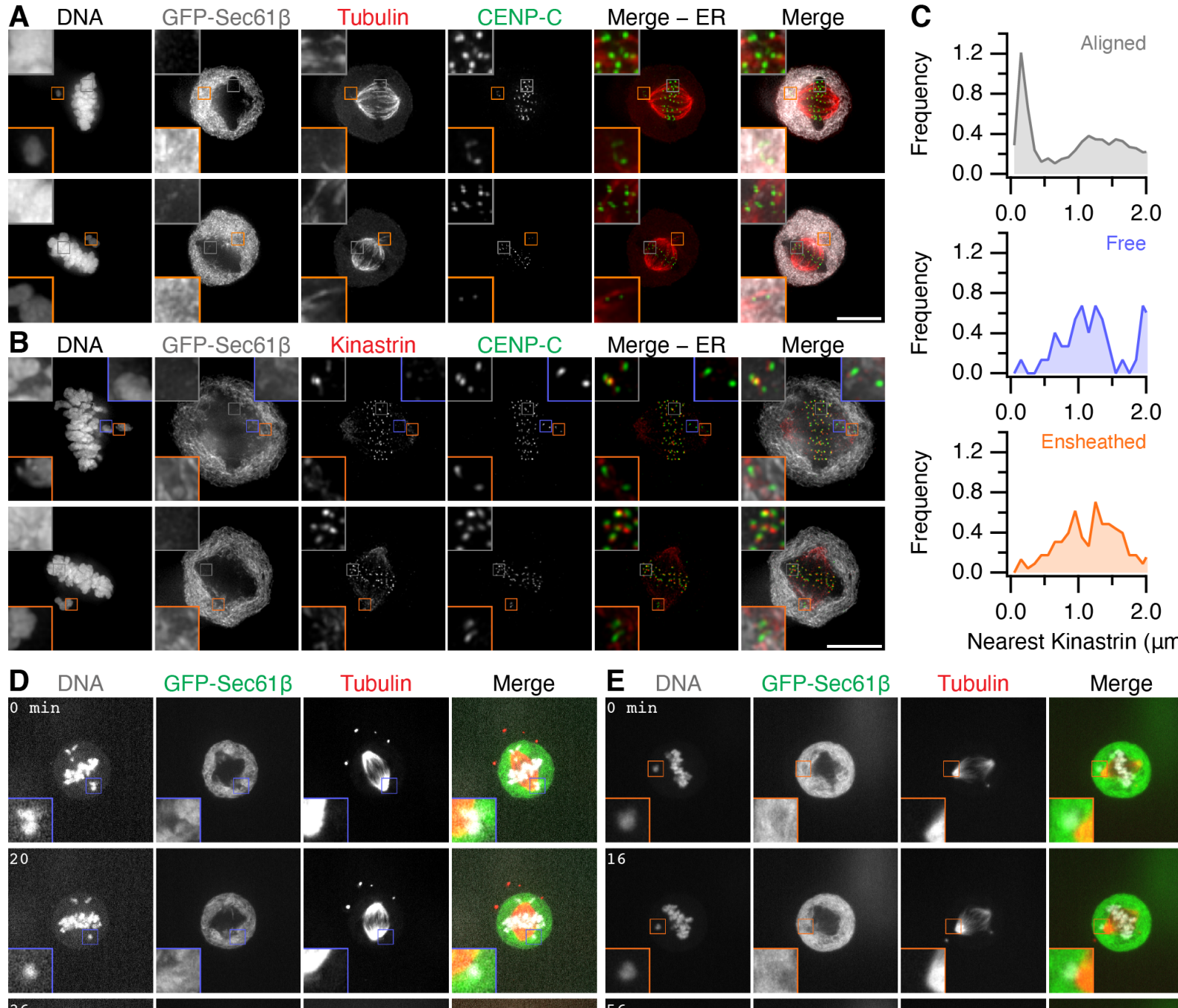

Nearest Kinastrin $(\mu \mathrm{m})$
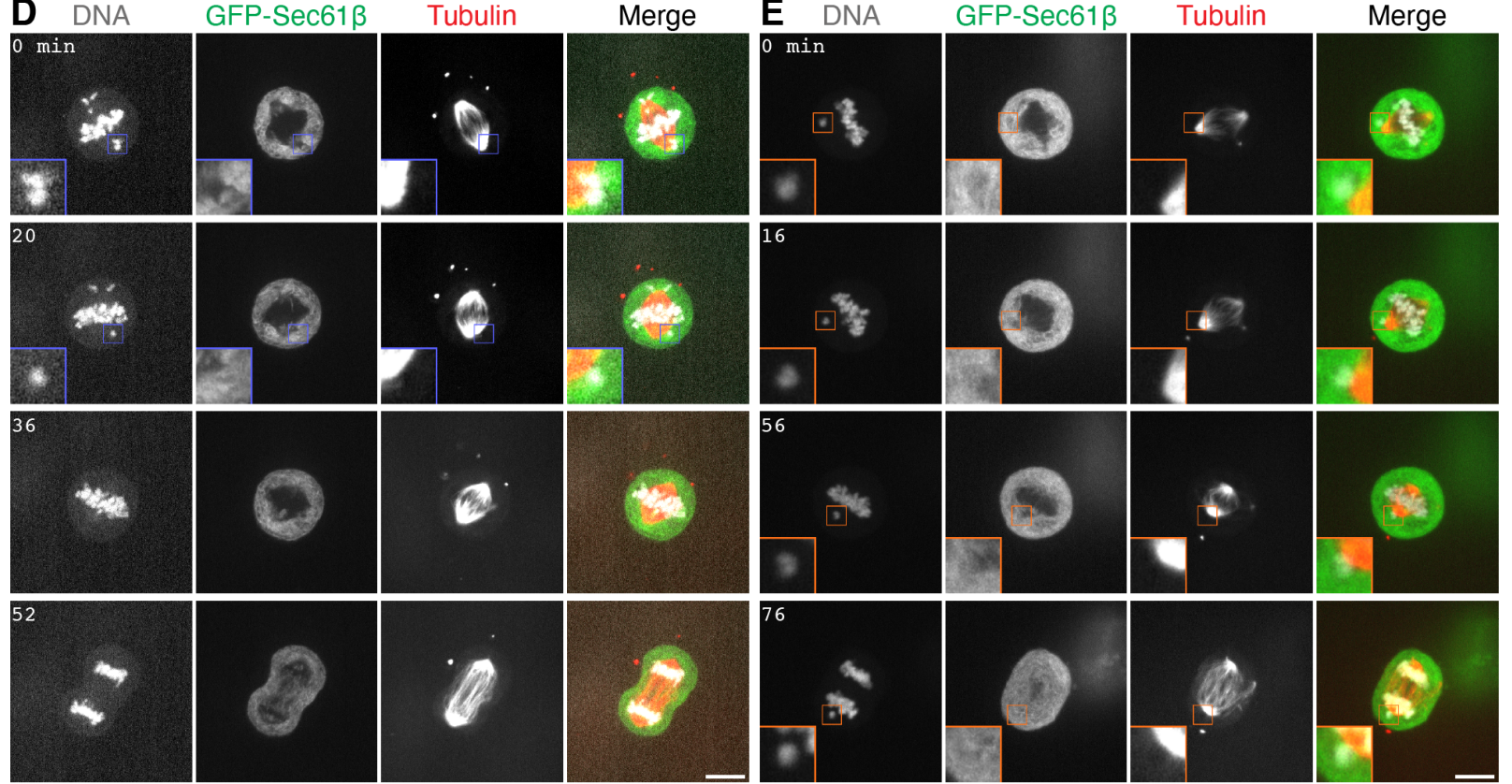

Figure 5. Ensheathed chromosomes do not have stable microtubule-kinetochore attachment

(A) Micrographs of RPE-1 cells stably expressing GFP-Sec61 $\beta$ (gray) pre-treated with GSK923295 immunostained for tubulin (red) and CENP-C (green), DNA stained with DAPI. Examples show end-on attachments at aligned kinetochores, and potential lateral kinetochore-MT contacts for ensheathed chromosomes. (B) Micrographs of RPE-1 cells stably expressing GFP-Sec61 $\beta$ (gray) pre-treated with GSK923295 immunostained for kinastrin (red) and CENP-C (green), DNA stained by DAPI. Scale bar, $10 \mu \mathrm{m}$. (C) Frequency distributions of the proximity of the nearest kinastrin punctum to each kinetochore (CENP-C punctum). Kinetochores (n, \% with kinastrin $<600 \mathrm{~nm}$ ): aligned $(3124,26.8 \%)$; free $(74,4.1 \%)$; ensheathed $(227,6.2 \%)$. (D-E) Still images from live-cell imaging experiments of RPE-1 cells stably expressing GFP-Sec61ß (green) and Histone H3.2-mCherry (gray), pre-treated with $150 \mathrm{nM}$ GSK923295 and stained with SiR-Tubulin (Tubulin, red). Rescue of a free chromosome is shown in (D) and missegregation of an ensheathed chromosome is shown in (E) (shown in Supplementary Videos SV6 and SV7). Similar results were recorded in 25 cells with free chromosomes and 16 cells with ensheathed chromosomes. Inset shows a $2 X$ zoom of the indicated region. Scale bar, $10 \mu \mathrm{m}$. 
bioRxiv preprint doi: https://doi.org/10.1101/2021.04.23.441091; this version posted September 2, 2021. The copyright holder for this preprint (which was not certified by peer review) is the author/funder, who has granted bioRxiv a license to display the preprint in perpetuity. It is made available under aCC-BY-NC 4.0 International license.
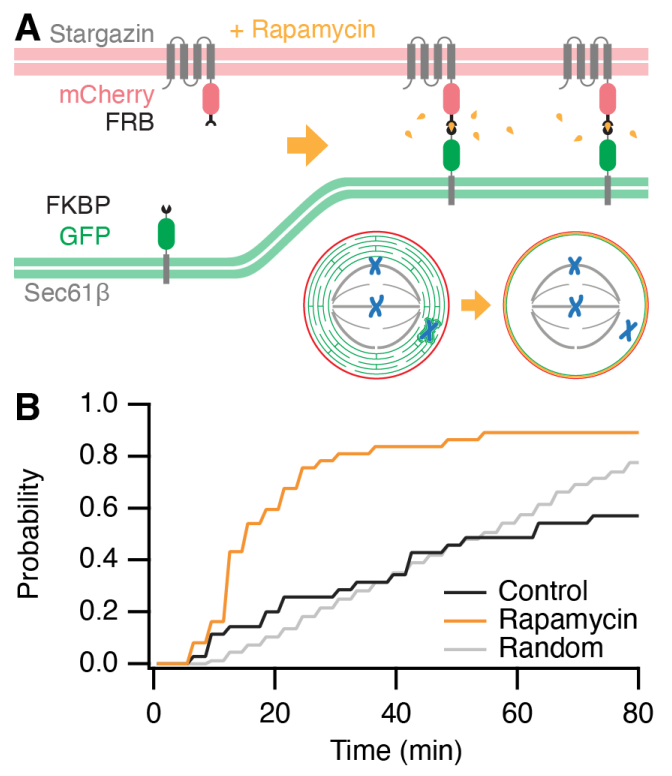

D

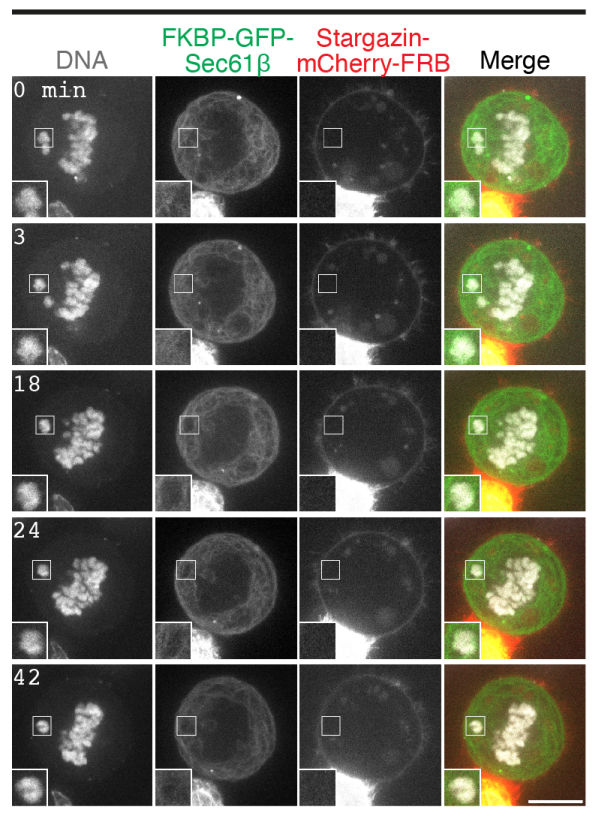

F Control

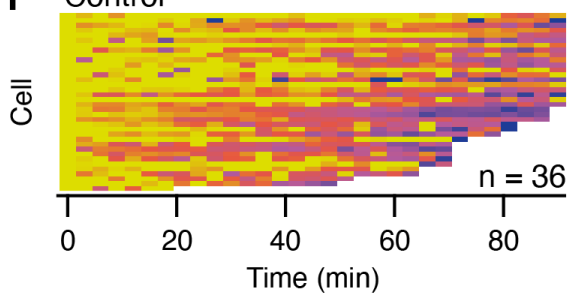

C

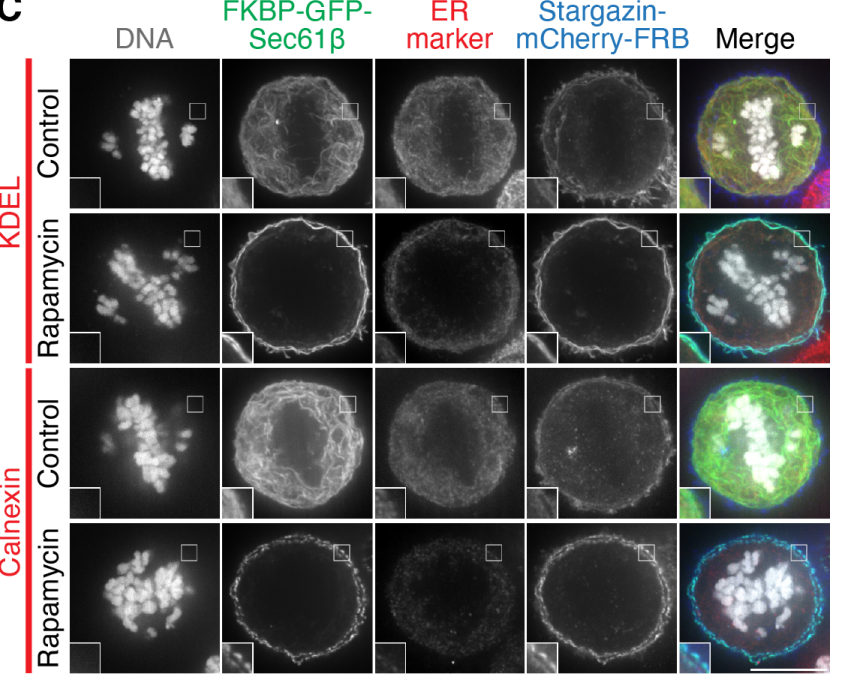

Rapamycin
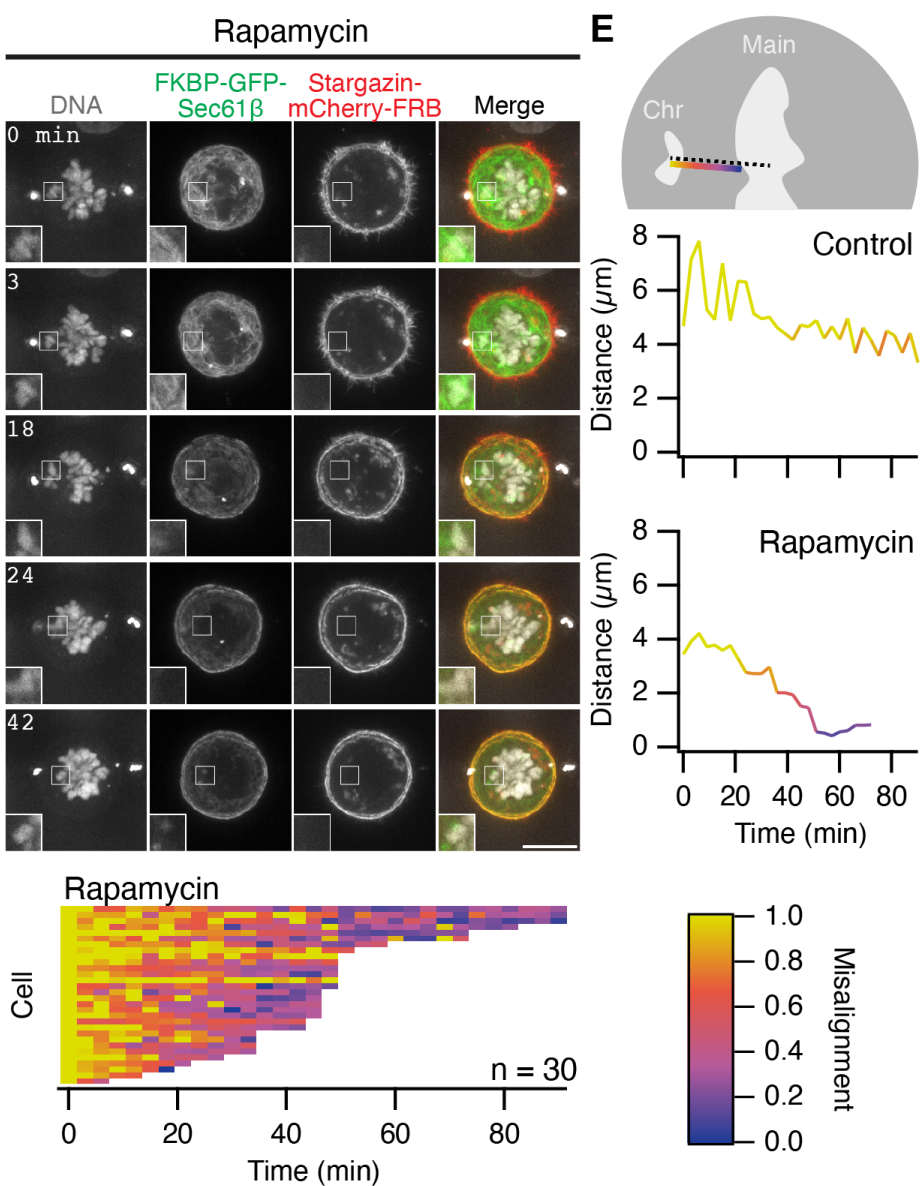

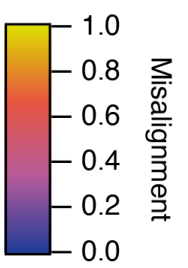

Figure 6. Rescue of ensheathed chromosomes by the induced relocalization of ER.

(A) Schematic diagram of the ER clearance procedure. Rapamycin induces the heterodimerization of the ER-resident FKBP-GFP-Sec61 $\beta$ and the plasma-membrane localized Stargazin-mCherry-FRB. (B) Cumulative histogram showing the time to detection of ER clearance. An automated segmentation procedure was used to monitor ER localization in mitotic cells. The time at which the largest decrease in ER localization occurred was taken (see Methods). Random occurrence is shown for comparison. The median (IQR) ER clearance time in Rapamycin-treated cells was 15 (12-24) minutes. (C) Induced relocalization of FKBP-GFP-Sec61 $\beta$ to the plasma membrane causes ER clearance. Typical immunofluorescence micrographs of mitotic HCT116 cells pre-treated with GSK923295, expressing FKBP-GFP-Sec61 $\beta$ (green) and Stargazin-mCherry-FRB (blue), treated or not with rapamycin (200 nM). Cells were stained for ER markers KDEL or Calnexin as indicated (red), DNA was stained with DAPI (gray). (D) Stills from live cell imaging of ER clearance experiments. FKBP-GFP-Sec61 $\beta$ (green), Stargazin-mCherry-FRB (red) and SiR-DNA (gray) are shown. Insets in $\mathrm{C}$ and D are $2 \mathrm{X}$ expansions of the ROI shown. Scale bars, $10 \mu \mathrm{m}$. See Supplementary Videos SV8. (E) Semi-automated 4D tracking of misaligned chromosome location is used to monitor congression. Two tracks from the cells in $\mathrm{D}$ are shown. The shortest Euclidean distance from the centroid of the misaligned chromosome to the edge of the main chromosome plate is plotted as a function of time. (F) Fate of misaligned chromosomes in control or Rapamycin-treated cells. Rescue of misaligned chromosomes was detected in 26 out of 30 Rapamycin-treated cells. Coloring in $\mathrm{E}$ and $\mathrm{F}$ is with the colorscale shown. Tracks terminate at $90 \mathrm{~min}$ or when the chromosome merges with the plate. Median termination time was 93 min (Control) and 45 min (Rapamycin); $p=7.1 \times 10^{-9}$, Wilcoxon Rank Test. In $\mathrm{B}, \mathrm{D}, \mathrm{E}$ and $\mathrm{F}$, rapamycin is applied after the first frame $(T=0)$. 
bioRxiv preprint doi: https://doi.org/10.1101/2021.04.23.441091; this version posted September 2, 2021. The copyright holder for this preprint (which was not certified by peer review) is the author/funder, who has granted bioRxiv a license to display the preprint in perpetuity. It is made available under aCC-BY-NC 4.0 International license.

chromosomes beyond the exclusion zone typically became ensheathed in endomembranes. Although the morphology of mitotic endomembranes varies between cell lines (Puhka et al., 2007; Lu et al., 2009, 2011; Puhka et al., 2012; Champion et al., 2017), all ensheathed chromosomes were draped in several layers of endomembranes. We use the term ensheathed to describe how these chromosomes are surrounded by endomembranes but not fully enclosed in any one layer as though in a vesicle. The ensheathing membrane follows the contours of the chromosome closely. Our SBF-SEM analysis did not uncover any obvious electron dense connections between the ensheathed chromosome and its surrounding membranes, although a previous report indicated that exogenous DNA clusters may physically interact with mitotic ER (Wang et al., 2016).

A major finding of our work is that ensheathing promotes missegregation and micronuclei formation. At first glance, it is difficult to see how microtubules can negotiate several layers of endomembranes in order to make the contact between kinetochore and spindle that is necessary for rescue and alignment. We found that lateral MT contacts with kinetochores were possible, in some cases, but that rescue of the chromosome was only likely for those chromosomes designated free. Our conclusion is that the endomembranes do not necessarily prevent contact with ensheathed chromosomes but they appear to make contact less likely or less productive. Even in cases where contact is made, endomembranes are likely to impair the congression of the chromosome, as suggested by a recent study where excess ER was shown to slow chromosome motions (Merta et al., 2021). Since endomembranes are a risk factor for missegregation, their precise organization - for example the sheet-to-tubule ratio of the ER - may influence the likelihood for missegregation (Champion et al., 2017). Besides impeding MT contacts and chromosome movement, a further explanation for how ensheathing may promote missegregation is by interfering with SAC signaling. We found that ensheathed chromosomes recruited SAC proteins, as expected for unattached kinetochores. The progression to anaphase may simply be explained by prolonged metaphase (Uetake and Sluder, 2010; Yang et al., 2008), another possibility is that the position of the kinetochore beyond the exclusion zone or even ensheathing itself prevents SAC signaling by 'smothering' this diffusible signal. A precedent for this possibility comes from experiments where two spindles are formed in one cell (Rieder et al., 1997). In that study, each spindle was in an individual exclusion zone, and SAC activation at one spindle did not affect the progression to anaphase at the other. Whatever the mechanism, the role of endomembranes in promoting missegregation may be important for tumor progression. It is possible that in tumor cells that are aneuploid, endomembranes may contribute to the higher rates of CIN observed (Funk et al., 2016; Nicholson and Cimini, 2015).

The fate of cells with ensheathed chromosomes was biased towards missegregation and formation of micronuclei. Interestingly, a previous study found that artificially tethering endomembranes to aligned chromosomes within the exclusion zone caused mitotic errors; although the outcome was dependent on when tethering was induced (Champion et al., 2019). Tethering prior to mitotic entry resulted in segregation errors and multilobed nuclei, whereas tethering during metaphase had little consequence. Although conceptually similar, the ensheathing process reported here is a natural consequence of a misaligned chromosome becoming entangled in endomembranes. Key differences include the position of the ensheathed chromosome, the lack of direct membrane-chromosome tethering, and multiple vs single endomembrane layers; these are likely to explain the different observed mitotic phenomena. We found that the micronuclei that result from ensheathed chromosomes had disrupted envelopes $8 \mathrm{~h}$ post-release from CENP-E inhibition. Rupture of micronuclei has been shown to lead to DNA damage, and activation of innate immune and cell invasion pathways (Ly et al., 2017; Hatch et al., 2013; Mammel et al., 2021; Bakhoum et al., 2018). The presence of ER in the micronuclear space of disrupted micronuclei indicates that ensheathing may increase the likelihood of rupture, we speculate that this may occur by endomembranes physically interfering with envelope reformation at the micronucleus.

Mitosis in human cells is open, yet we have known for over 60 years that the spindle exists in a membrane-free ellipsoid exclusion zone (Bajer, 1957; Porter and Machado, 1960; Nixon et al., 2017). It seems intuitive that the spindle must operate in a membrane-free area to avoid errors, but recent work suggests that the exclusion zone is actively maintained and that this arrangement is important for concentrating factors for spindle assembly (Schweizer et al., 2015) or for maintenance of spindle structure (Kumar et al., 2019; Schlaitz et al., 2013). We found that ER clearance, via an induced relocalization strategy, could be used as an intervention to improve the outcome for mitotic cells with ensheathed chromosomes. Induced relocalization of small organelles has previously been demonstrated (Dunlop et al., 2017; Hirst et al., 2015; Larocque et al., 2020; van Bergeijk et al., 2015), but the movement of a large organellar network by similar means had not been attempted previously. Surprisingly, ER clearance in mitotic cells was efficient, although it was much slower than the relocalization of intracellular nanovesicles, taking tens of minutes rather than tens of seconds (Larocque et al., 2020). We speculate that the efficiency of clearance is due to cooperativity of relocalization since the FKBP-GFP-Sec61 $\beta$ molecules are dispersed in the ER which is interconnected. These experiments were important to show that ensheathing was causal for chromosome missegregation. We note that this method has many future applications: to selectively perturb mitotic structures, at defined times, during cell division. For example, ER clearance and concomitant expansion of the exclusion zone is an ideal manipulation to probe the function of this enigmatic cellular region.

\section{Methods}

Molecular biology. The following plasmids were gifts, available from Addgene, or from previous work as indicated: Histone H3.2-mCherry (A. Bowman, University of Warwick), pAc-GFPC1-Sec61 $\beta$ (Addgene \#15108), psPAX2 (Addgene \#12260), pMD2.G (Addgene \#12259), pWPT-GFP (Addgene \#12255), Stargazin-GFP-LOVpep (Addgene \#80406), LBR pEGFP-N1 (Addgene \#61996), EGFP-BAF (addgene \#101772), pMito-mCherry-FRB (Addgene \#59352), Histone H2B-mCherry (Cheeseman et al., 2013), pFKBP-GFP-C1 (Clarke and Royle, 2018)

To generate a plasmid to express mCherry-Sec61 $\beta$, EcoRI-Bglll digestion product of pAc-GFPC1-Sec61 $\beta$ was ligated into pmCherry-C1 vector (made by substituting mCherry for EGFP in pEGFP-C1 (Clontech) by Agel-Xhol digestion). LBR-mCherry was made by amplifying the LBR 
bioRxiv preprint doi: https://doi.org/10.1101/2021.04.23.441091; this version posted September 2, 2021. The copyright holder for this preprint (which was not certified by peer review) is the author/funder, who has granted bioRxiv a license to display the preprint in perpetuity. It is made available under aCC-BY-NC 4.0 International license.

insert from LBR in pEGFP-N2 and ligating into pmCherry-N1 using $\mathrm{Kpnl}$ and BamHI. The mCherry-BAF construct was amplified from EGFP-BAF and inserted into pmCherry-C1 using Bglll and HindllI.

For Lentivirus transfer plasmids, constructs for expression were cloned into pWPT-GFP using Mlul-Sall sites or Mlul-BstBI for LBR-mCherry.

Plasmids for ER clearance were generated as follows. For FKBP-GFP-Sec61 $\beta$, a BgllI-EcoRI fragment from pAc-GFP-C1-Sec61 $\beta$ was ligated into pFKBP-GFP-C1. Stargazin-mCherry-FRB construct was made by PCR of Stargazin encoding region from Stargazin-GFP-LOVpep and insertion into pMito-mCherry-FRB at Nhel-BamHI sites.

Cell biology. HCT116 (ATCC, CCL-247) and HEK293T (ATCC, CRL-11268) cells were maintained in Dulbecco's Modified Eagle's Medium (DMEM) supplemented with $10 \%$ FBS and $100 \mathrm{U} \mathrm{ml}^{-1}$ penicillin/streptomycin. DLD1-WT and DLD1-C-H3 (Ly et al., 2017), gifts from Don Cleveland (UCSD). These cell lines and their derivatives were maintained in DMEM supplemented with $10 \%$ Tetra-Free FBS (D2-118, SLS), $2 \mathrm{mM}$ L-glutamine, $100 \mathrm{U} \mathrm{ml}^{-1}$ penicillin/streptomycin and $100 \mathrm{ug} \mathrm{ml}^{-1}$ hygromycin. RPE-1 (Horizon Discovery) and derived cell lines were maintained in DMEM/F-12 Ham supplemented with $10 \%$ FBS, $2 \mathrm{mM}$ L-glutamine, $100 \mathrm{U} \mathrm{ml}^{-1}$ penicillin/streptomycin and $0.26 \%$ sodium bicarbonate $\left(\mathrm{NaHCO}_{3}\right)$. All cell lines were incubated in a humidified incubator at $37^{\circ} \mathrm{C}$ and $5 \% \mathrm{CO}_{2}$. Cells were routinely tested for mycoplasma contamination by a PCR-based method.

RPE-1 GFP-Sec61 $\beta$ stable cell line was generated by Fugene-HD (Promega) transfection of pAc-GFPC1-Sec61 $\beta$. DLD1-WT mCherry-Sec61 $\beta$ and DLD1-C-H3 mCherry-Sec61 $\beta$ stable cell lines were generated by GeneJuice (Merck Millipore) transfection of mCherry-Sec61 $\beta$ into the respective parental lines. Individual clones were isolated by $\mathrm{G} 418$ treatment $\left(500 \mu \mathrm{g} \mathrm{ml}^{-1}\right)$ and were validated using a combination of western blot, FACS and fluorescence microscopy. Stable co-expression of Histone H3.2-mCherry, mCherry-BAF or LBR-mCherry with GFP-Sec61 $\beta$ in RPE-1 cells was achieved by lentiviral transduction. Individual cells positive for GFP and mCherry signal were sorted by FACS and single cell clones validated by fluorescence microscopy. Note that the transgenic expression of GFP-Sec61 $\beta$ is associated with downregulation of endogenous Sec61 $\beta$ (Supplementary Figure S3A). Transient transfections of HCT116, RPE-1 and HeLa were done using Fugene-HD or GeneJuice according to the manufacturer's instructions.

For lentiviral transduction, HEK293T packaging cells were incubated in DMEM supplemented with $10 \%$ FBS, $2 \mathrm{mM}$ L-glutamine, and $25 \mu \mathrm{M}$ chloroquine diphosphate (C6628, Sigma) for $3 \mathrm{~h}$. Transfection constructs were prepared at $1.3 \mathrm{pm}$ psPAX2 (Addgene \#12260), 0.72pM pMD2.G (Addgene \#12259) and $1.64 \mathrm{pM}$ transfer plasmid (encoding the tagged protein to be expressed) in OptiPro SFM. Polyethylenimine (PEI) dilution in OptiPro SFM was prepared separately at $1: 3$ ratio with DNA (w/w, DNA:PEI) in the transfection mixture. Transfection mixes were combined, incubated at room temperature for $15 \mathrm{~min}$ to $20 \mathrm{~min}$, and then added to the packaging cells. Cells were incubated for $18 \mathrm{~h}$, after which the media was replaced with DMEM supplemented with $10 \% \mathrm{FBS}$ and $100 \mathrm{U} \mathrm{ml}^{-1}$ penicillin/streptomycin. Viral particles were harvested $48 \mathrm{~h}$ post-transfection. Viral supernatant was centrifuged and filtered before applying to target cells. Target cells were then infected through incubation in media containing $8 \mathrm{\mu g} \mathrm{ml}^{-1}$ polybrene (408727, Sigma) for $16 \mathrm{~h}$ to $20 \mathrm{~h}$. Media was replaced with complete media and cells were screened after $24 \mathrm{~h}$. All incubations were in a humidified incubator at $37^{\circ} \mathrm{C}$ and $5 \% \mathrm{CO}_{2}$.

To induce misaligned chromosomes in RPE-1 or HCT116 cell lines, cells were incubated in complete media containing $150 \mathrm{nM}$ GSK923295 (Selleckchem) for $3 \mathrm{~h}$ before release of cells from treatment. For fixed cell experiments, release was for $1 \mathrm{~h}$. To induce the auxin-degron system in DLD-1 cells, $500 \mu \mathrm{m}$ indole-3-acetic (A10556, Fisher) and $500 \mathrm{\mu g} \mathrm{ml}^{-1}$ doxycycline (Sigma, D9891) were added to the media and cells incubated for $24 \mathrm{~h}$.

ER clearance was induced through application of rapamycin (Alfa Aesar) to final concentration of $200 \mathrm{nM}$, to HCT116 cells expressing FKBP-GFP-Sec61 $\beta$ and stargazin-mCherry-FRB. For fixed cell experiments, rapamycin treatment was for $30 \mathrm{~min}$.

Fluorescence methods. For immunofluorescence, cells were fixed at room temperature using PFA solution (3\% formaldehyde, $4 \%$ sucrose in phosphate-buffered saline (PBS)) for $15 \mathrm{~min}$ and permeabilized at room temperature in $0.5 \%(\mathrm{v} / \mathrm{v})$ Triton $\mathrm{X}-100$ in PBS for $10 \mathrm{~min}$. Cells were blocked in $3 \% \mathrm{BSA}$ in PBS for $60 \mathrm{~min}$ at room temperature. Cells were then incubated for $60 \mathrm{~min}$ at room temperature with primary antibody dilutions prepared in $3 \%$ BSA in PBS as follows: mouse anti-Bub1 (ab54893, Abcam, 1:500); mouse anti-Mad2 (sc-65492, Santa Cruz, 1/200); rabbit anti-calnexin (ab22595, Abcam, 1:200); guinea pig anti-CENP-C (PD030, Medical and Biological Labs Company, 1:2000); rabbit anti-H3K27ac (ab4729, Abcam, 1:1000); rabbit anti-KDEL (PA1-013, Invitrogen, 1:200); rabbit anti-kinastrin (HPA042027, Atlas Antibodies, 1:1000). Following three PBS washes, cells were incubated with secondary antibodies for $60 \mathrm{~min}$, either Alexa Fluor568- or Alexa Fluor647-conjugated antibody in 3\% BSA/PBS (Invitrogen, 1:500). Following three PBS washes, coverslips were rinsed and mounted with Vectashield containing 4',6-diamidino-2-phenylindole (DAPI, Vector Laboratories), then sealed. In cases where GFP signal required amplification, cells were incubated with GFP-booster (Alexa Fluor488, Chromotek, 1:200) at the secondary antibody step. Where amplification of mCherry was required, mouse anti-mCherry (1C51 - ab125096, Abcam, 1:500) was used with AlexaFluor568-conjugated secondary antibody.

For fluorescent in situ hybridization (FISH) of DLD-1 WT and DLD1-C-H3 cells, the degron system was induced and cells synchronised by doubled thymidine $(2.5 \mathrm{~mm})$ treatment. Samples were fixed in Carnoy's fixative (3:1 v/v methanol:glacial acetic acid) for $5 \mathrm{~min}$ at room temperature, then rinsed in fixative, before addition of fresh fixative and incubated for a further $10 \mathrm{~min}$. Samples were rinsed in distilled water before FISH probe denaturation and hybridization following the manufacturer's protocol (Xcyting Centromere Enumeration Probe, XCE Y green, D-0824-050-FI, MetaSystems Probes).

To dye chromosomes or microtubules in fixed or live cell imaging, cells were incubated for $30 \mathrm{~min}$ with $0.5 \mu \mathrm{M}$ SiR-DNA or SiR-Tubulin (Spirochrome), respectively.

Biochemistry. For western blot, cells were harvested, and lysates prepared by sonication of cells in UTB buffer (8 M Urea, $50 \mathrm{~mm}$ TRIS, $150 \mathrm{~mm} \beta$-mercaptoethanol). Lysates 
bioRxiv preprint doi: https://doi.org/10.1101/2021.04.23.441091; this version posted September 2, 2021. The copyright holder for this preprint (which was not certified by peer review) is the author/funder, who has granted bioRxiv a license to display the preprint in perpetuity. It is made available under aCC-BY-NC 4.0 International license.

were incubated on ice for $30 \mathrm{~min}$, clarified in a benchtop centrifuge $(20800 \mathrm{~g})$ for $15 \mathrm{~min}$ at $4{ }^{\circ} \mathrm{C}$, then boiled in Laemmli buffer for $10 \mathrm{~min}$ and resolved on a precast $4 \%-15 \%$ polyacrylamide gel (Bio-Rad). Proteins were transferred to nitrocellulose using a Trans-Blot Turbo Transfer System (Bio-Rad). Primary antibodies were diluted in $4 \% \mathrm{BSA}$ in PBS and used as follows: rabbit anti-Sec61 $\beta$ (PA3-015, Invitrogen, 1:1000); HRP conjugated mouse anti- $\beta$-actin (sc-47778, Santa Cruz, 1: 20000); rabbit anti-mCherry (ab183628, Abcam, 1:2000); anti-GAPDH (G9545, Sigma, 1/5000); rabbit anti-CENP-A (2186, Cell Signalling, 1:1000);

Secondary antibodies of anti-mouse, -rabbit and -rat IgG HRP conjugates were prepared in $5 \%$ milk in PBS. For detection, enhanced chemiluminescence detection reagent (GE Healthcare) and manual exposure of Hyperfilm (GE Healthcare) was performed.

Microscopy. For fixed cell imaging experiments, a Personal DeltaVision microscope system (Applied Precision, LLC), based on an IX-71 microscope body (Olympus) was used with a CoolSNAP HQ2 interline CCD camera (Photometrics) and a 60x oil-immersion 1.42 NA oil PlanApo $\mathrm{N}$ objective. Equipped with Precision Control microscope incubator, Tokai Hit stage top incubator and Applied Precision motorised $x y z$ stage. Illumination was via a Lumencor SPECTRA $X$ light engine (DAPI, 395/25; GFP, 470/24; mCherry, 575/25; CY-5, 640/30), dichroics (Quad: Reflection 381-401:464-492:531-556:619-644 Transmission 409-456:500-523:564-611:652-700; GFP/mCh: Reflection 464-492:561-590 Transmission 500-553:598-617) and filter sets (DAPI: ex 387/11 em 457/50; GFP: ex 470/40 em 525/50; TRITC: ex 575/25 em 597/45; mCherry: ex 572/28 em 632/60; CY-5: ex 640/14 em 685/40). Image capture was by softWoRx 5.5.1 (Applied Precision). Images were deconvolved using softWoRx 3.0 with the following settings: conservative ratio, 15 cycles and high noise-filtering.

For live cell imaging, cells were plated onto fluorodishes (WPI) and imaged in complete media in an incubated chamber at $37^{\circ} \mathrm{C}$ and $5 \% \mathrm{CO}_{2}$. Most live cell imaging was done using a Nikon CSU-W1 spinning disc confocal system with SoRa upgrade (Yokogawa) was used with either a Nikon, 100x, 1.49, oil, CFI SR HP Apo TIRF or a $63 \times, 1.40$ NA, oil, CFI Plan Apo objective (Nikon) with optional 2.3x intermediate magnification and 95B Prime camera (Photometrics). The system has CSU-W1 (Yokogawa) spinning disk unit with 50 um and SoRa disks (SoRa disk used), Nikon Perfect Focus autofocus, Okolab microscope incubator, Nikon motorised xy stage and Nikon $200 \mu \mathrm{m}$ z-piezo. Excitation was via $405 \mathrm{~nm}$, $488 \mathrm{~nm}, 561 \mathrm{~nm}$ and $638 \mathrm{~nm}$ lasers with 405/488/561/640 nm dichroic and Blue, 446/60; Green, 525/50; Red, 600/52; FRed, $708 / 75$ emission filters. Acquisition and image capture was via NiS Elements (Nikon).

For mitotic progression and fate experiments, the DeltaVision system described above was used. For live cell imaging of HeLa cells or of the single cell fate of RPE- 1 cells, a spinning disc confocal system (UltraView VoX, PerkinElmer) with a 60x, 1.40 , oil, Plan Apo VC objective (Nikon) was used. Images were captured using an ORCA-R2 digital charge-coupled device camera (Hamamatsu) following excitation with $488 \mathrm{~nm}$ and $561 \mathrm{~nm}$ lasers, and 405/488/561/640 nm dichroic and $525 / 50,615 / 70$ filter sets. Images were captured using Volocity 6.3.1.

All microscopy data was stored in an OMERO database in native file formats.
Serial block face-scanning electron microscopy. To prepare samples for serial block face-scanning electron microscopy (SBF-SEM), RPE-1 GFP-Sec61 $\beta$ on gridded dishes were first incubated with $150 \mathrm{nM}$ GSK923295 (Selleckchem) for $3 \mathrm{~h}$ to induce misaligned chromosomes, before release of cells from treatment and incubation for around $30 \mathrm{~min}$ with $0.5 \mu \mathrm{M}$ SiR-DNA (Spirochrome) to visualise DNA. HeLa cells on gridded dishes were not treated and were not stained. Using live cell light microscopy, cells with an ensheathed chromosome were selected for SBF-SEM. Fluorescent and brightfield images of the selected cell were captured and the coordinate position recorded. Cells were washed twice with PB (phosphate buffer) before fixing $(2.5 \%$ glutaraldehyde, $2 \%$ paraformaldehyde, $0.1 \%$ tannic acid (low molecular weight) in $0.1 \mathrm{M}$ phosphate buffer, $\mathrm{pH}$ 7.4) for $1 \mathrm{~h}$ at room temperature. Samples were washed three times with $\mathrm{PB}$ and then post-fixed in $2 \%$ reduced osmium (equal volume of $4 \% \mathrm{OsO}_{4}$ prepared in water and $3 \%$ potassium ferrocyanide in $0.1 \mathrm{M}$ PB solution) for $1 \mathrm{~h}$ at room temperature, followed by a further three washes with PB. Cells were then incubated for $5 \mathrm{~min}$ at room temperature in $1 \%(\mathrm{w} / \mathrm{v})$ thiocarbohydrazide solution, followed by three PB washes. A second osmium staining step was then included, incubating cells in a $2 \% \mathrm{OsO}_{4}$ solution prepared in water for $30 \mathrm{~min}$ at room temperature, followed by three washes with PB. Cells were then incubated in $1 \%$ uranyl acetate solution at $4{ }^{\circ} \mathrm{C}$ overnight. This was followed by a further three washes with PB. Walton's lead aspartate was prepared adding $66 \mathrm{mg}$ lead nitrate (TAAB) to $9 \mathrm{ml} 0.03 \mathrm{M}$ aspartic acid solution at $\mathrm{pH}$ 4.5 , and then adjusting to final volume of $10 \mathrm{ml}$ with $0.03 \mathrm{M}$ aspartic acid solution and to $\mathrm{pH} 5.5 \mathrm{pH}$ adjustments with $\mathrm{KOH}$ ). Cells were incubated in Walton's lead aspartate for $30 \mathrm{~min}$ at room temperature and then washed three times in PB. Samples were dehydrated in an ethanol dilution series (30\%, 50\%, 70\%, $90 \%$, and $100 \%$ ethanol, 5 min incubation in each solution) on ice, then incubated for a further $10 \mathrm{~min}$ in $100 \%$ ethanol at room temperature. Finally, samples were embedded in an agar resin (AGAR 100 R1140, Agar Scientific).

SBF-SEM data was segmented using Microscopy Image Browser version 2.60 and the resulting $3 \mathrm{D}$ model was visualized in IMOD version 4.10 .49 (Belevich et al., 2016; Kremer et al., 1996). HeLa SBF-SEM data was segmented and reconstructed in Amira 6.7 (Thermo Fisher Scientific).

Data analysis. Kinetochore position analysis was in two parts. First, the position of kinetochores and spindle poles in hyperstacks were manually mapped using Cell Counter in Fiji. The kinetochore pointsets were classified into three categories: those aligned at the metaphase plate and those that were misaligned, with this latter group subdivided into kinetochores of chromosomes that were ensheathed and those that were not (free). Second, the ER channel of the hyperstack was segmented in Fiji to delineate the exclusion zone. Next, the Cell Counter XML files and their respective binarized ER stacks were read by program written in Igor Pro (WaveMetrics). To analyze the position of points relative to the exclusion zone in each cell, the ratio of two Euclidean distances was calculated (see Equation 1). Where $C$ is the centroid of all aligned kinetochores, $P_{i}$ is the position of a kinetochore and $Q_{i}$ is the point on the path from $C$ through $P$, where the exclusion zone/ER boundary intersects with the path. 
bioRxiv preprint doi: https://doi.org/10.1101/2021.04.23.441091; this version posted September 2, 2021. The copyright holder for this preprint (which was not certified by peer review) is the author/funder, who has granted bioRxiv a license to display the preprint in perpetuity. It is made available under aCC-BY-NC 4.0 International license.

$$
\overline{\overline{C P_{i}}}
$$

The ratio of these two distances gave a measure of how deep the point was placed inside or outside the exclusion zone ( 0 being on the boundary and 1 being as far outside of the exclusion zone as from the centroid to the boundary, on a log2 scale).

For analysis of nuclear envelope re-formation kinetics in RPE-1 cells stably expressing GFP-Sec61 $\beta$ and either mCherry-BAF or LBR-mCherry, treated with GSK923295 to induce misaligned polar chromosomes, a threshold was first applied to allow selection of misaligned chromosome and main chromosome mass regions. Intensity measures (mean pixel densities) of fluorescence at the regions of interest were measured for every frame. To demonstrate the kinetics of any recruitment of mCherry-BAF or LBR-mCherry during mitosis, the values were normalized to the value at anaphase (time 0 ). Automated kinetochore-kinastrin colocalization was using a script that located the 3D position of kinetochores (CENP-C) and kinastrin puncta from thresholded images using 3D Object Counter in Fiji. These positions were loaded into Igor and the Euclidean distance to the nearest kinastrin punctum from each kinetochore was found.

ER clearance experiments were quantified using two automated procedures. First, ER, DNA and plasma membrane were segmented separately and then the plasma membrane segments were used to define the cell and the total area of segmented ER within this region was measured for all z-positions over time using a FIJl macro. Data were read by lgor and the ER volume over time was calculated. ER clearance manifested as a rapid decrease in ER volume, but the onset was variable. The derivative of ER volume of time was used to find the point of rapid decrease and this point was used to define the time to ER clearance. Random fluctuations in otherwise constant ER volume over time also resulted in a minima that occurred randomly. This process was modeled and plotted for comparison with the control group, where no clearance was seen. Second, the segmented DNA was classified into misaligned chromosome and main chromosome mass by a user blind to the conditions of the experiment. 3D coordinates of these two groups were fed into lgor where the centroids and boundaries of the chromosome and main chromosome mass where defined. The closest Euclidean distance between the centroid of the chromosome and edge of the main chromosome mass was used as the distance. Misalignment, shown as a colorscale, is this distance normalized to the starting distance.

Figures were made with FIJI, R or Igor Pro, and assembled using Adobe Illustrator. Null hypothesis statistical tests were done as described in the figure legends.

Data and software availability. All code used in the manuscript is available at https://github.com/quantixed/Misseg

\section{ACKNOWLEDGEMENTS}

We thank Claire Mitchell and Laura Cooper from the Computing and Advanced Microscopy Unit (CAMDU) for their help and support. Faye Nixon, Alison Beckett and lan Prior at the Liverpool Biomedical EM Unit provided SBF-SEM imaging. We are grateful to Richard Bayliss, Vishakha Karnawat, Jonathan Millar, Alonso Pardal and James Shelford for feedback on the project and manuscript. This work was supported by a Pioneer Award and Programme Award from Cancer Research UK (C25425/A24167 and C25425/A27718). LD was supported by a studentship from BBSRC Midlands Integrative Biosciences Training Partnership (MIBTP) (BB/M01116X/1)

AUTHOR CONTRIBUTIONS
$\mathrm{NF}$, conceptualization, investigation, resources, supervision, writing - original draft, writing - review \& editing. LD, formal analysis, investigation, resources, writing - review \& editing. GS, visualization. SJR, formal analysis, funding acquisition, software, supervision, visualization, writing - original draft, writing - review \& editing.

COMPETING FINANCIAL INTERESTS

The authors declare no conflict of interest.

\section{Bibliography}

Bajer, A. (1957). Ciné-micrographic studies on mitosis in endosperm. III. The origin of the mitotic spindle. Exp Cell Res 13, 493-502. doi: 10.1016/0014-4827(57)90078-2.

Bakhoum, S. F., Ngo, B., Laughney, A. M., Cavallo, J.-A., Murphy, C. J., Ly, P., Shah, P., Sriram, R. K., Watkins, T. B. K., Taunk, N. K., Duran, M., Pauli, C., Shaw, C., Chadalavada, K., Rajasekhar, V. K., Genovese, G., Venkatesan, S., Birkbak, N. J., McGranahan, N., Lundquist, M., LaPlant, Q., Healey, J. H., Elemento, O., Chung, C. H., Lee, N. Y., Imielenski, M., Nanjangud, G., Pe'er, D., Cleveland, D. W., Powell, S. N., Lammerding, J., Swanton, C., and Cantley, L. C. (2018). Chromosomal instability drives metastasis through a cytosolic DNA response. Nature 553, 467-472. doi: 10. 1038 /nature25432.

Belevich, I., Joensuu, M., Kumar, D., Vihinen, H., and Jokitalo, E. (2016). Microscopy Image Browser: A Platform for Segmentation and Analysis of Multidimensional Datasets. PLoS Biol 14, e1002340. doi: 10.1371/journal.pbio.1002340.

Champion, L., Linder, M. I., and Kutay, U. (2017). Cellular Reorganization during Mitotic Entry. Trends Cell Biol 27, 26-41. doi: 10.1016/j.tcb.2016.07.004.

Champion, L., Pawar, S., Luithle, N., Ungricht, R., and Kutay, U. (2019). Dissociation of membrane-chromatin contacts is required for proper chromosome segregation in mitosis. Mol Biol Cell 30, 427-440. doi: 10.1091/mbc.E18-10-0609.

Cheeseman, L. P., Harry, E. F., McAinsh, A. D., Prior, I. A., and Royle, S. J. (2013). Specific removal of TACC3-ch-TOG-clathrin at metaphase deregulates kinetochore fiber tension. J Cell Sci 126, 2102-2113. doi: 10.1242/jcs.124834.

Cimini, D., Howell, B., Maddox, P., Khodjakov, A., Degrassi, F., and Salmon, E. D. (2001). Merotelic kinetochore orientation is a major mechanism of aneuploidy in mitotic mammalian tissue cells. J Cell Biol 153, 517-527. doi: 10.1083/jcb.153.3.517.

Clarke, N. I. and Royle, S. J. (2018). FerriTag is a new genetically-encoded inducible tag for correlative light-electron microscopy. Nat Commun 9, 2604. doi: 10.1038/ s41467-018-04993-0.

Crasta, K., Ganem, N. J., Dagher, R., Lantermann, A. B., Ivanova, E. V., Pan, Y., Nezi, L., Protopopov, A., Chowdhury, D., and Pellman, D. (2012). DNA breaks and chromosome pulverization from errors in mitosis. Nature 482, 53-58. doi: 10.1038/nature10802.

Daum, J. R., Potapova, T. A., Sivakumar, S., Daniel, J. J., Flynn, J. N., Rankin, S., and Gorbsky, G. J. (2011). Cohesion fatigue induces chromatid separation in cells delayed at metaphase. Curr Biol 21, 1018-1024. doi: 10.1016/j.cub.2011.05.032.

Duijf, P. H. G. and Benezra, R. (2013). The cancer biology of whole-chromosome instability. Oncogene 32, 4727-4736. doi: 10.1038/onc.2012.616

Dunlop, M. H., Ernst, A. M., Schroeder, L. K., Toomre, D. K., Lavieu, G., and Rothman, J. E. (2017). Land-locked mammalian Golgi reveals cargo transport between stable cisternae. Nat Commun 8, 432. doi: 10.1038/s41467-017-00570-z

Dunsch, A. K., Linnane, E., Barr, F. A., and Gruneberg, U. (2011). The astrin-kinastrin/SKAP complex localizes to microtubule plus ends and facilitates chromosome alignment. J Cell Biol 192, 959-968. doi: 10.1083/jcb.201008023.

Fujiwara, T., Bandi, M., Nitta, M., Ivanova, E. V., Bronson, R. T., and Pellman, D. (2005). Cytokinesis failure generating tetraploids promotes tumorigenesis in p53-null cells. Nature 437, 1043-1047. doi: 10.1038/nature04217.

Funk, L. C., Zasadil, L. M., and Weaver, B. A. (2016). Living in CIN: Mitotic Infidelity and Its Consequences for Tumor Promotion and Suppression. Dev Cell 39, 638-652. doi: 10.1016/j.devcel.2016.10.023.

Ghadimi, B. M., Sackett, D. L., Difilippantonio, M. J., Schröck, E., Neumann, T., Jauho, A., Auer, G., and Ried, T. (2000). Centrosome amplification and instability occurs exclusively in aneuploid, but not in diploid colorectal cancer cell lines, and correlates with numerical chromosomal aberrations. Genes Chromosomes Cancer 27, 183-190.

Hatch, E. M., Fischer, A. H., Deerinck, T. J., and Hetzer, M. W. (2013). Catastrophic nuclear envelope collapse in cancer cell micronuclei. Cell 154, 47-60. doi: $10.1016 / \mathrm{j}$.cell. 2013.06.007.

Hepler, P. K. and Wolniak, S. M. (1984). Membranes in the mitotic apparatus: their structure and function. Int Rev Cytol 90, 169-238. doi: 10.1016/s0074-7696(08)61490-4.

Hirst, J., Edgar, J. R., Borner, G. H. H., Li, S., Sahlender, D. A., Antrobus, R., and Robinson, M. S. (2015). Contributions of epsinR and gadkin to clathrin-mediated intracellular trafficking. Mol Biol Cell 26, 3085-3103. doi: $10.1091 / \mathrm{mbc}$. E15-04-0245.

Kalitsis, P., Earle, E., Fowler, K. J., and Choo, K. H. (2000). Bub3 gene disruption in mice reveals essential mitotic spindle checkpoint function during early embryogenesis. Genes Dev 14, 2277-2282. doi: 10.1101/gad.827500.

Kremer, J. R., Mastronarde, D. N., and McIntosh, J. R. (1996). Computer visualization of three-dimensional image data using IMOD. J Struct Biol 116, 71-76. doi: 10.1006/ jsbi.1996.0013.

Kumar, D., Golchoubian, B., Belevich, I., Jokitalo, E., and Schlaitz, A.-L. (2019). REEP3 and REEP4 determine the tubular morphology of the endoplasmic reticulum during mitosis. Mol Biol Cell 30, 1377-1389. doi: 10.1091/mbc.E18-11-0698.

Larocque, G., La-Borde, P. J., Clarke, N. I., Carter, N. J., and Royle, S. J. (2020). Tumo protein D54 defines a new class of intracellular transport vesicles. J Cell Biol 219. doi: $10.1083 /$ jcb.201812044.

Liu, S., Kwon, M., Mannino, M., Yang, N., Renda, F., Khodjakov, A., and Pellman, D. (2018). Nuclear envelope assembly defects link mitotic errors to chromothripsis. Nature 561, 551-555. doi: 10.1038/s41586-018-0534-z. 
bioRxiv preprint doi: https://doi.org/10.1101/2021.04.23.441091; this version posted September 2, 2021. The copyright holder for this preprint (which was not certified by peer review) is the author/funder, who has granted bioRxiv a license to display the preprint in perpetuity. It is made available under aCC-BY-NC 4.0 International license.

Lu, L., Ladinsky, M. S., and Kirchhausen, T. (2009). Cisternal organization of the endoplasmic reticulum during mitosis. Mol Biol Cell 20, 3471-3480. doi: 10.1091/ mbc.e09-04-0327.

Lu, L., Ladinsky, M. S., and Kirchhausen, T. (2011). Formation of the postmitotic nuclear envelope from extended ER cisternae precedes nuclear pore assembly. I Cell Biol 194, 425-440. doi: $10.1083 /$ jcb.201012063.

Ly, P., Teitz, L. S., Kim, D. H., Shoshani, O., Skaletsky, H., Fachinetti, D., Page, D. C., and Cleveland, D. W. (2017). Selective Y centromere inactivation triggers chromosome shattering in micronuclei and repair by non-homologous end joining. Nat Cell Biol 19, 68-75. doi: $10.1038 /$ ncb3450.

Mammel, A. E., Huang, H. Z., Gunn, A. L., Choo, E., and Hatch, E. M. (2021). Chromosome length and gene density contribute to micronuclear membrane stability. preprint, Cell Biology. URL http://biorxiv.org/lookup/doi/10.1101/2021.05. 12.443914 .

Merta, H., Carrasquillo Rodríguez, J. W., Anjur-Dietrich, M. I., Granade, M. E., Vitale, T., Harris, T. E., Needleman, D. J., and Bahmanyar, S. (2021). A CTDNEP1-lipin 1-mTOR regulatory network restricts ER membrane biogenesis to enable chromosome motions necessary for mitotic fidelity. preprint, Cell Biology. URL http://biorxiv . org/ lookup/doi/10.1101/2021.03.02.433553.

Nicholson, J. M. and Cimini, D. (2015). Link between aneuploidy and chromosome instability. Int Rev Cell Mol Biol 315, 299-317. doi: 10.1016/bs.ircmb.2014.11.002.

Nixon, F. M., Honnor, T. R., Clarke, N. I., Starling, G. P., Beckett, A. J., Johansen, A. M. Brettschneider, J. A., Prior, I. A., and Royle, S. J. (2017). Microtubule organization within mitotic spindles revealed by serial block face scanning electron microscopy and image analysis. J Cell Sci 130, 1845-1855. doi: 10.1242/jcs. 203877.

Porter, K. R. and Machado, R. D. (1960). Studies on the endoplasmic reticulum. IV. Its form and distribution during mitosis in cells of onion root tip. J Biophys Biochem Cytol 7, 167-180. doi: 10.1083/jcb.7.1.167.

Puhka, M., Vihinen, H., Joensuu, M., and Jokitalo, E. (2007). Endoplasmic reticulum remains continuous and undergoes sheet-to-tubule transformation during cell division in mammalian cells. J Cell Biol 179, 895-909. doi: 10.1083/jcb.200705112.

Puhka, M., Joensuu, M., Vihinen, H., Belevich, I., and Jokitalo, E. (2012). Progressive sheet-to-tubule transformation is a general mechanism for endoplasmic reticulum partitioning in dividing mammalian cells. Mol Biol Cell 23, 2424-2432. doi: 10.1091/ mbc.E10-12-0950.

Rieder, C. L., Khodjakov, A., Paliulis, L. V., Fortier, T. M., Cole, R. W., and Sluder, G. (1997). Mitosis in vertebrate somatic cells with two spindles: implications for the metaphase/anaphase transition checkpoint and cleavage. Proc Natl Acad Sci U S A 94, 5107-5112. doi: 10.1073 /pnas.94.10.5107.

Schlaitz, A.-L., Thompson, J., Wong, C. C. L., Yates, J. R., and Heald, R. (2013). REEP3/4 ensure endoplasmic reticulum clearance from metaphase chromatin and proper nuclear envelope architecture. Dev Cell 26, 315-323. doi: 10.1016/j.devcel.2013.06.016.

Schweizer, N., Pawar, N., Weiss, M., and Maiato, H. (2015). An organelle-exclusion envelope assists mitosis and underlies distinct molecular crowding in the spindle region. J Cell Biol 210, 695-704. doi: 10.1083/jcb.201506107.

Uetake, Y. and Sluder, G. (2010). Prolonged prometaphase blocks daughter cell proliferation despite normal completion of mitosis. Curr Biol 20, 1666-1671. doi: 10.1016/j.cub. 2010.08.018.

van Bergeijk, P., Adrian, M., Hoogenraad, C. C., and Kapitein, L. C. (2015). Optogenetic control of organelle transport and positioning. Nature 518, 111-114. doi: 10.1038/ nature 14128

Vedrenne, C., Klopfenstein, D. R., and Hauri, H.-P. (2005). Phosphorylation controls CLIMP-63-mediated anchoring of the endoplasmic reticulum to microtubules. $\mathrm{Mol}$ Biol Cell 16, 1928-1937. doi: 10.1091/mbc.e04-07-0554.

Wang, X., Le, N., Denoth-Lippuner, A., Barral, Y., and Kroschewski, R. (2016). Asymmetric partitioning of transfected DNA during mammalian cell division. Proc Nat Acad Sci U S A 113, 7177-7182. doi: 10.1073/pnas.1606091113.

Warren, G. (1993). Membrane partitioning during cell division. Annu Rev Biochem 62, 323-348. doi: 10.1146/annurev.bi.62.070193.001543.

Wood, K. W., Lad, L., Luo, L., Qian, X., Knight, S. D., Nevins, N., Brejc, K., Sutton, D., Gilmartin, A. G., Chua, P. R., Desai, R., Schauer, S. P., McNulty, D. E., Annan, R. S. Belmont, L. D. Garcia, C., Lee, Y., Diamond, M. A., Faucette, L. F., Giardiniere, M. Zhang, S., Sun, C.-M., Vidal, J. D., Lichtsteiner, S., Cornwell, W. D., Greshock, J. D. Wooster, R. F., Finer, J. T., Copeland, R. A., Huang, P. S., Morgans, D. J., Dhanak, D., Bergnes, G., Sakowicz, R., and Jackson, J. R. (2010). Antitumor activity of an allosteric inhibitor of centromere-associated protein-E. Proc Natl Acad Sci U S A 107, 5839-5844. doi: $10.1073 /$ pnas.0915068107.

Yang, Z., Loncarek, J., Khodjakov, A., and Rieder, C. L. (2008). Extra centrosomes and/or chromosomes prolong mitosis in human cells. Nat Cell Biol 10, 748-751. doi: 10.1038/ ncb1738. 


\section{Supplementary Information}
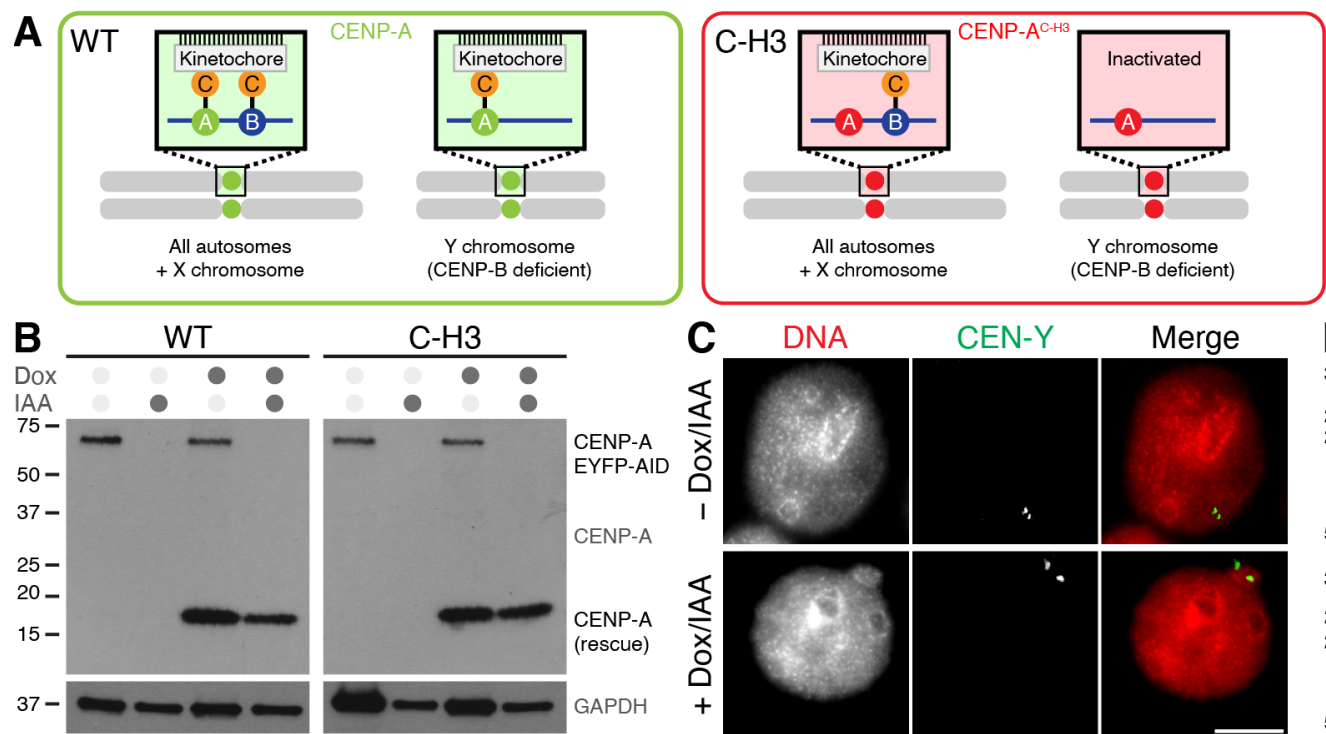

Stable expression

$\mathrm{G} 2=$

WT + mCherry-Sec61 $\beta$

G11 $=$

$\mathrm{C}-\mathrm{H} 3+$ mCherry-Sec61 $\beta$
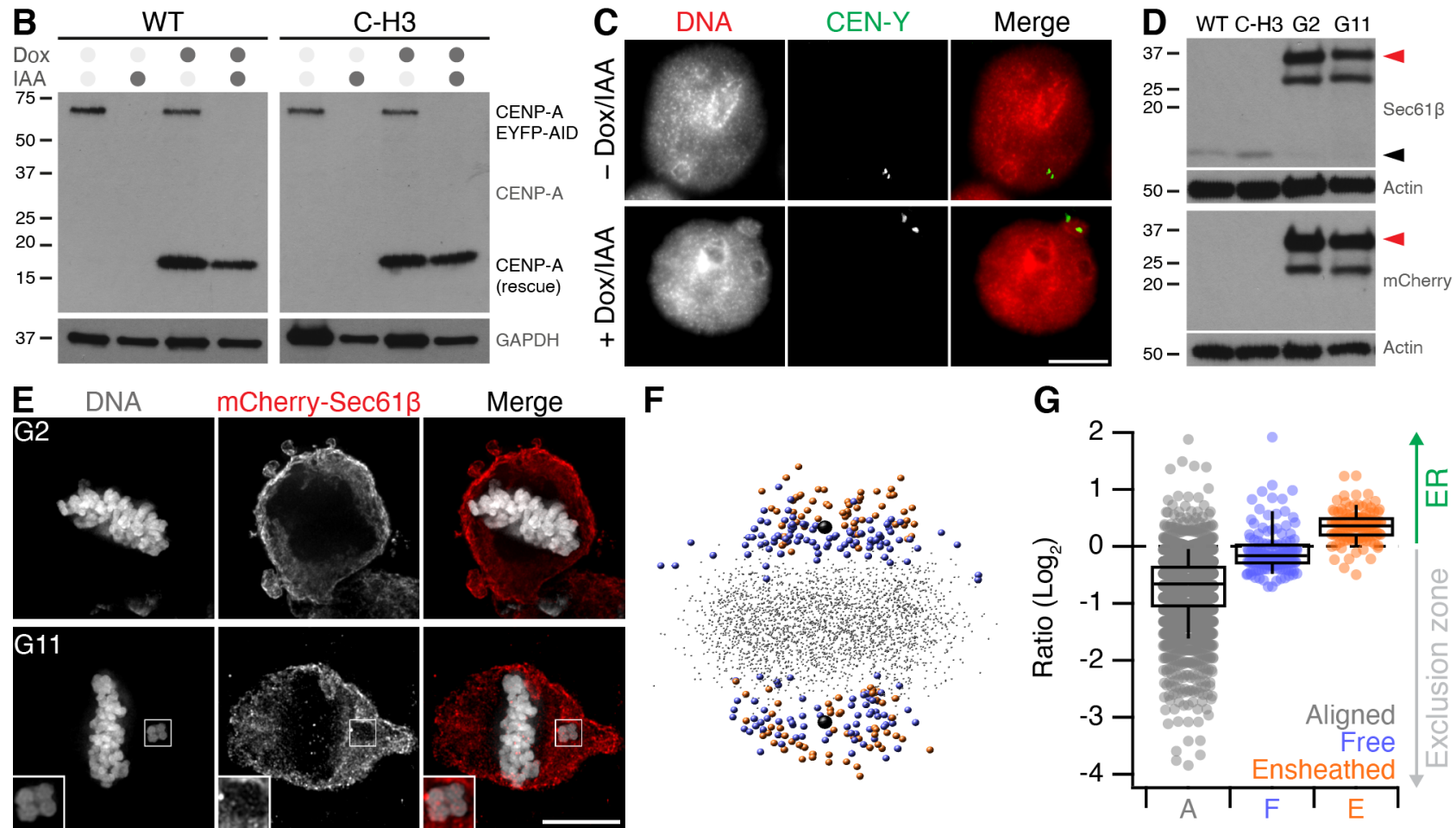

$\mathbf{F}$

G
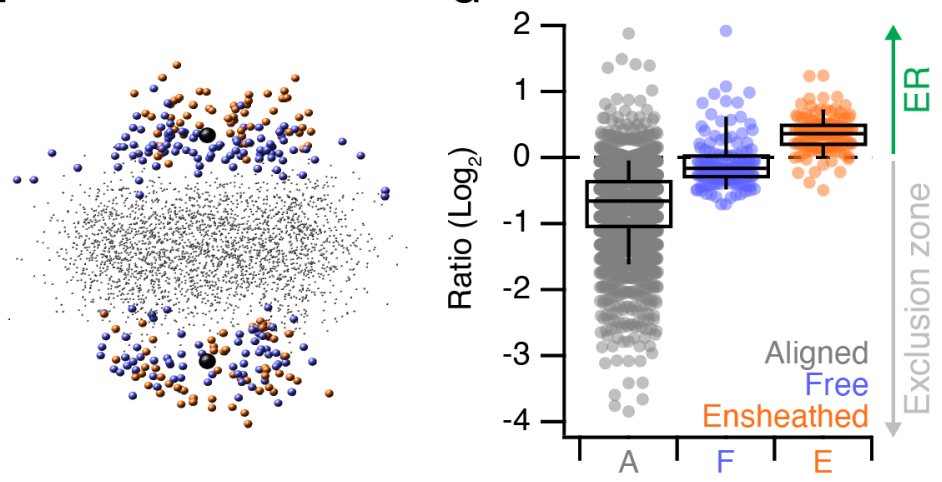

Figure S1. Ensheathed chromosomes in DLD-1 cells after targeted missegregation of Y-chromosome.

(A) Schematic diagram after Ly et al. 2017, showing how re-expression of a CENP-A mutant (C-H3) in DLD-1 cells where CENP-A is degraded causes selective misalignment of the $\mathrm{Y}$-chromosome. WT and C-H3 lines were further modified to express mCherry-Sec61 $\beta$. (B) Western blot of lysates from WT or C-H3 DLD-1 cells treated with doxycycline (Dox) and/or indole-3-acetic acid (IAA) as indicated. Upper blot shows anti-CENP-A detection of endogenous CENP-A fused to EYFP-AID tag (66 kDa and expression of untagged CENP-A (either WT or C-H3). Lower blot shows GAPDH loading control. (C) Typical FISH images locating the Y-chromosome in the main nucleus in control cells and in a micronucleus in cells expressing C-H3 CENP-A. (D) Western blot of lysates from stable cell lines expressing mCherry-Sec61 $\beta$ derived from WT (G2) or C-H3 (G11). Detection of Sec61 $\beta$ or mCherry is shown as indicated with actin loading controls. Migration of Sec61 $\beta$ and mCherry-Sec61 $\beta$ are indicated by black and red arrowheads respectively. Note the expression of mCherry-Sec61 $\beta$ downregulates endogenous Sec61 $\beta$. (E) Deconvolved widefield microscopy images showing an ensheathed chromosome in G11 cells but not in G2 cells treated with Dox/IAA. (F) Spatially averaged view of all kinetochores in the G11 DLD-1 Dox/IAA dataset (see Methods). Small gray points represent kinetochores at the metaphase plate. Colored points represent misaligned chromosomes that were ensheathed (orange) and those that were not (blue). Spindle poles are shown in black. (G) Box plot to show the relative position of each kinetochore relative to the exclusion zone boundary. Ratio of kinetochores within the exclusion zone are $<0$ and those within the ER are $>0$ on a log2 scale. Dots represent kinetochore ratios from 50 of DLD-1 cells at metaphase. Boxes show IQR, bar represents the median and whiskers show 9th and 91st percentiles. 
bioRxiv preprint doi: https://doi.org/10.1101/2021.04.23.441091; this version posted September 2, 2021. The copyright holder for this preprint (which was not certified by peer review) is the author/funder, who has granted bioRxiv a license to display the preprint in perpetuity. It is made available under aCC-BY-NC 4.0 International license.
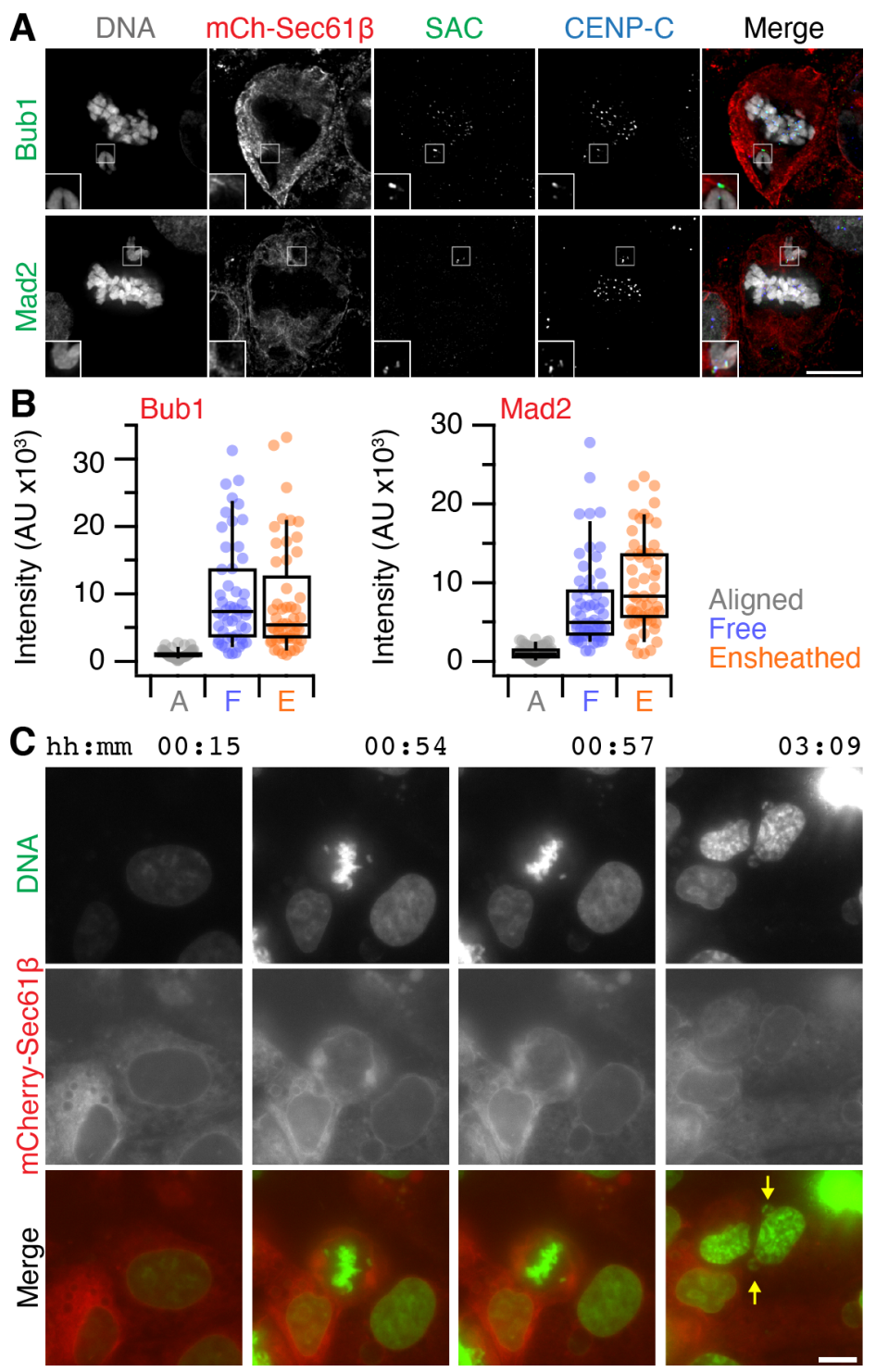

Figure S2. Spindle assembly checkpoint and micronuclei formation in DLD-1 cells

(A) Micrographs of immunofluorescence experiments to detect Bub1 or Mad2 (SAC, Green) at kinetochores (CENP-C, blue) in cells stably expressing mCherry-Sec61 $\beta$ (red), DAPI-stained DNA is shown in gray. Scale bar, $10 \mu \mathrm{m}$. (B) Quantification of Bub1 and Mad2 immunofluorescence at kinetochores marked by CENP-C. Ensheathed chromosomes were classified using the mCherry-Sec61 $\beta$ signal. (C) Stills from a movie showing an example of ensheathed chromosomes in G11 DLD-1 cells forming micronuclei following Dox/IAA treatment. Scale, $10 \mu \mathrm{m}$. 
bioRxiv preprint doi: https://doi.org/10.1101/2021.04 23.441091. this version posted September 2, 2021. The copyright holder for this preprint (which was not certified by peer review) is the author/funder, who has granted bioRxiv a license to display the preprint in perpetuity. It is made available under aCC-BY-NC 4.0 International license.

A
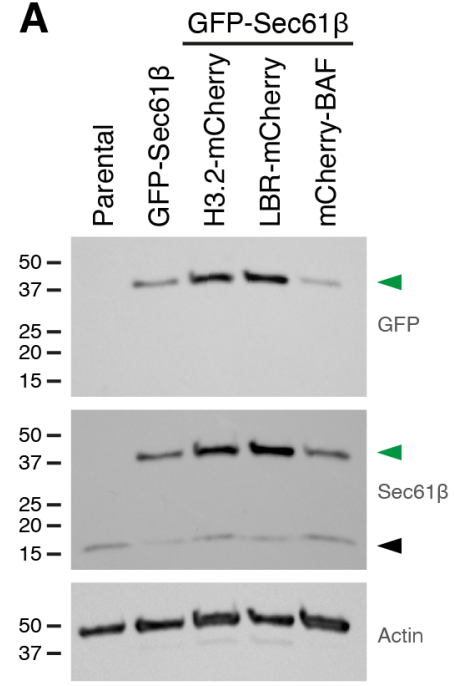

B

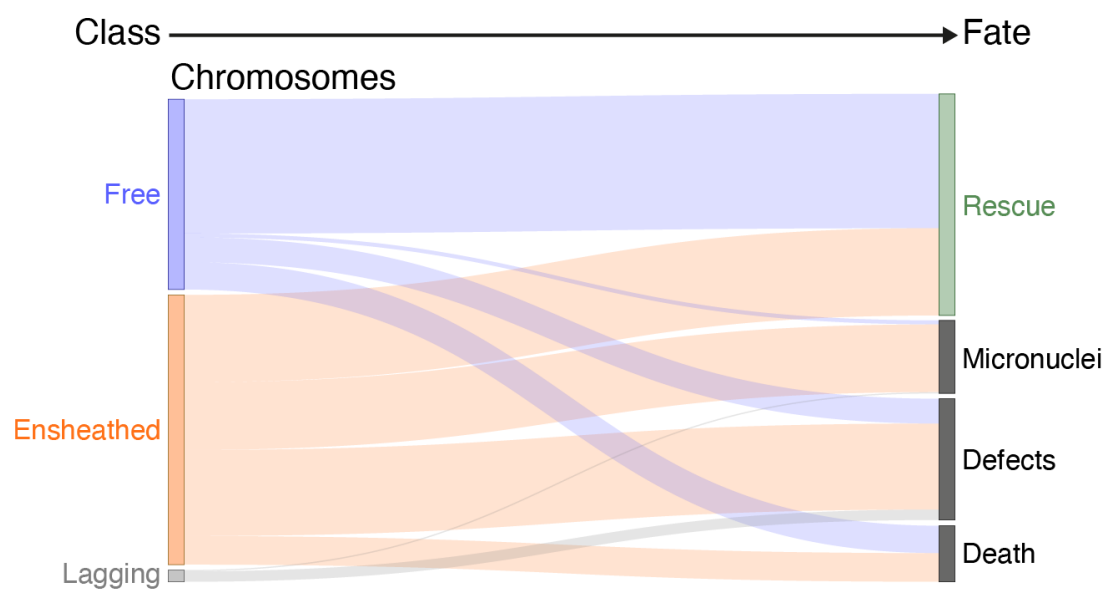

Figure S3. Stable expression of tagged Sec61 $\beta$ in RPE1 cells and fate of misaligned chromosomes

(A) Expression of Sec61 $\beta$ and GFP-Sec61 $\beta$ in parental RPE1 cells or clonal cells stably expressing GFP-Sec61 $\beta$ and either Histone3.2-mCherry, LBR-mCherry or mCherry-BAF. Western blots for GFP, Sec61 $\beta$ and actin (loading control) are shown, green and black arrowheads indicate the expected position of GFP-Sec61 $\beta$ and Sec61 $\beta$, respectively. (B) Sankey diagram to show the fate (right) of chromosomes in each of the three metaphase classes (left) after GSK923295 pre-treatment. Fates include rescue, micronuclei formation, death and other defects (lagging chromosome, cytokinesis failure). The same dataset was analyzed for the outcome of cells (classified by the final misaligned chromosome) in Figure 3. Note that ensheathed chromosomes at metaphase that were rescued all became "free" chromosomes prior to rescue. 

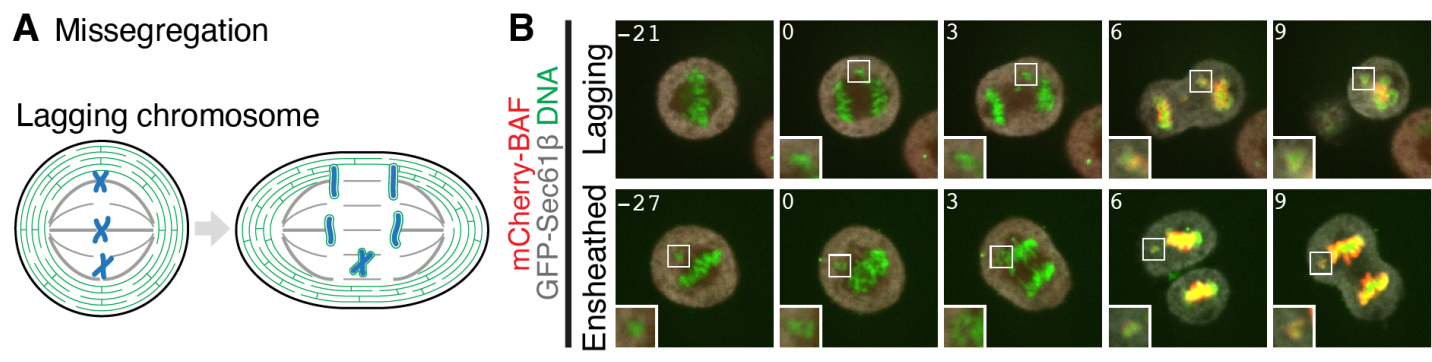

Ensheathed chromosome
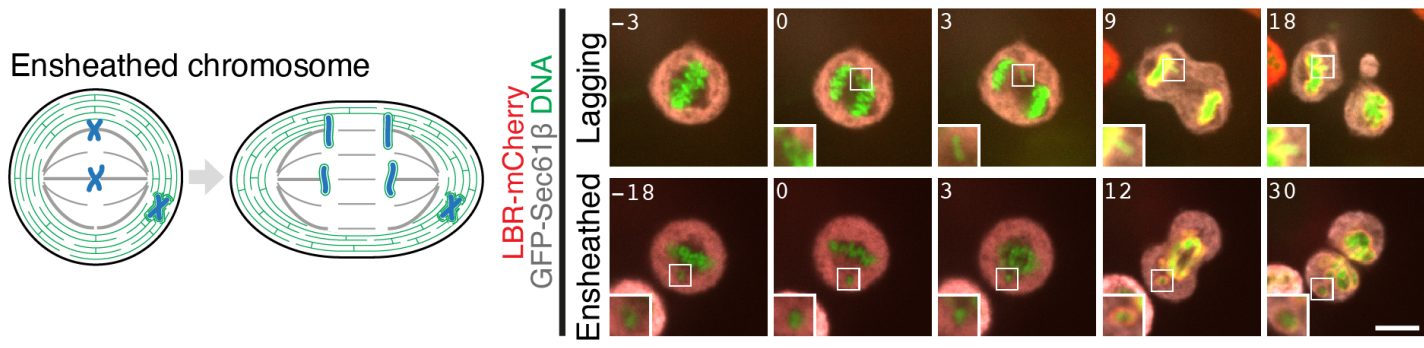

C

mCherry-BAF + GFP-Sec61ß

LBR-mCherry + GFP-Sec61ß
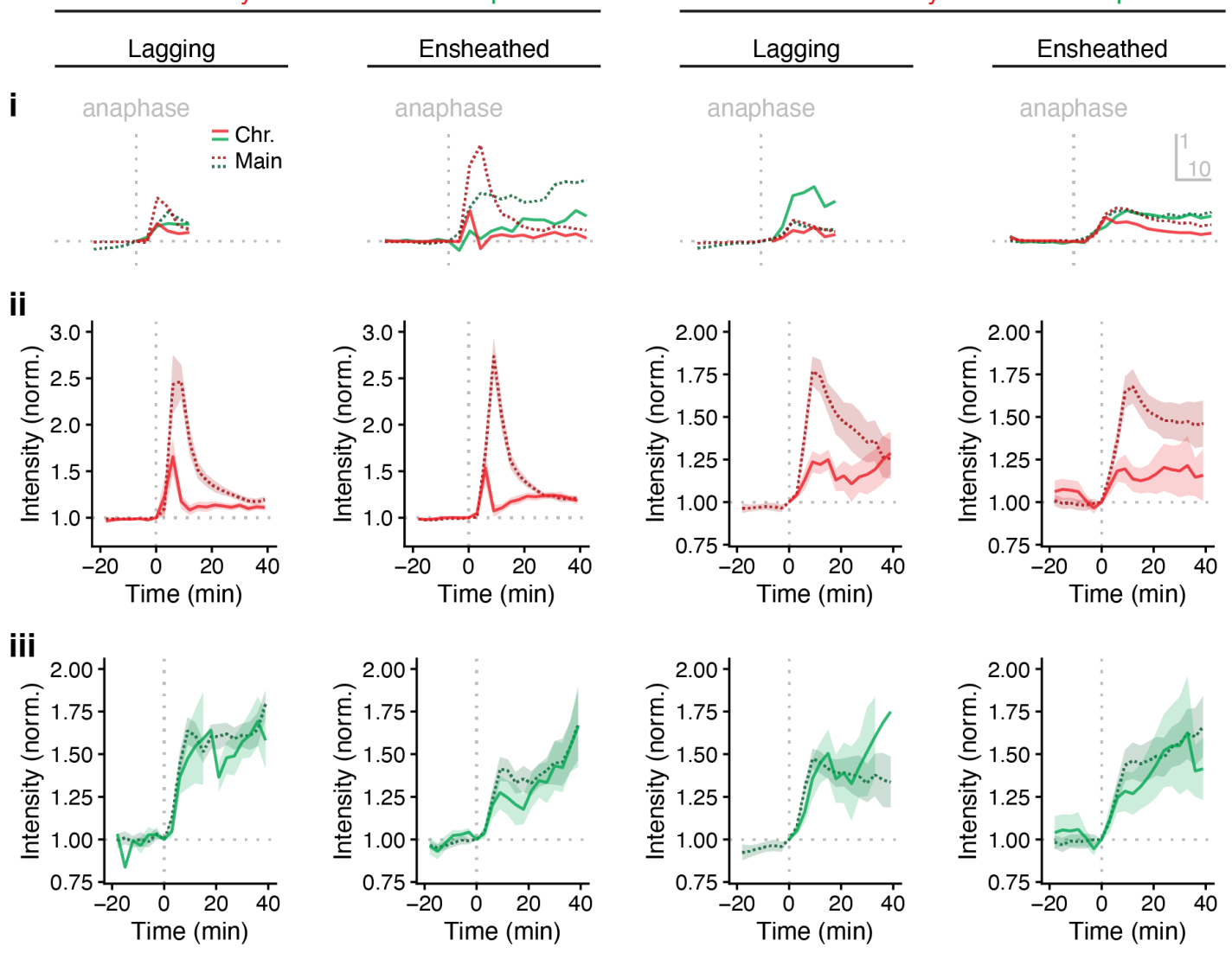

Figure S4. Kinetics of mCherry-BAF and LBR-mCherry recruitment to micronuclei

(A) Schematic diagram of two types of missegregated chromsome. A lagging chromosome situated between the two daughter chromosome masses which arises due to missegregation at anaphase; and a misaligned ensheathed chromosome. (B) Still images from typical widefield movies of RPE-1 cells stably expressing GFP-Sec61 $\beta$ (ER, gray) and either mCherry-BAF or LBR-mCherry (red), pre-treated with $150 \mathrm{nM}$ GSK923295 and stained with SiR-DNA (green). Examples show either a lagging chromosome or an ensheathed chromosome. Time in min relative to anaphase onset $(0 \mathrm{~min})$ is shown top left. Inset shows a $2 \times$ zoom of the chromosome. Scale bar, $10 \mu \mathrm{m}$. (C) Recruitment of GFP-Sec61 $\beta$ and either mCherry-BAF (left) or LBR-mCherry (right) at either lagging or ensheathed chromosomes, compared to the main nuclear mass. (i) Example traces from individual examples shown in A. Scale shows 1 unit of intensity and $10 \mathrm{~min}$, time of anaphase onset is indicated. (ii) Average intensity of mCherry-BAF (left) or LBR-mCherry (right) at chromosome (light red) or main mass (dark red). (iii), average intensity of GFP-Sec61 $\beta$ at chromosome (light green) or main mass (dark green). Traces were normalized to the value at anaphase, offset and averaged. Lines show the average \pm SD. 

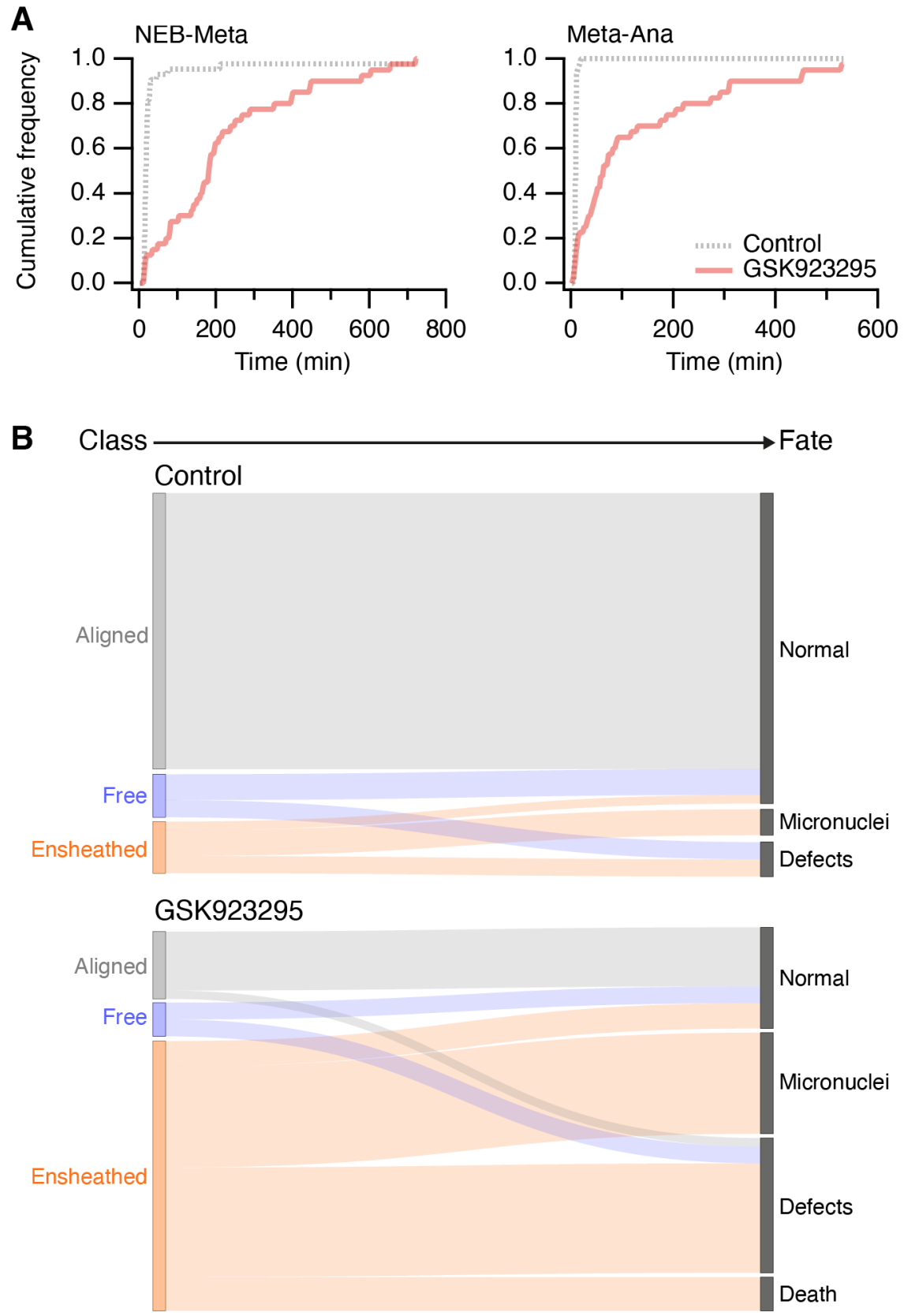

Figure S5. Mitotic timing and fate of HCT116 cells pre-treated with CENP-E inhibitor

(A) Mitotic timing of HCT116 cells. Cumulative frequencies for nuclear envelope breakdown to metaphase (NEB-Meta) and metaphase to anaphase (Meta-Ana) are shown. Cells were treated with $150 \mathrm{nM}$ GSK923295 for $3 \mathrm{~h}$ before washout for $1 \mathrm{~h}$ and subsequent imaging. Control, $n=43$, GSK pre-treatment, $n=40$; pooled from three experiments. (B) Sankey diagram to show the fate (right) of cells in each of the three metaphase classes (left). Fates include normal division, micronuclei formation, death and other defects (lagging chromosome, cytokinesis failure). Note that the fate of cells (and not chromosomes) is tracked. 
bioRxiv preprint doi: https://doi.org/10.1101/2021.04.23.441091; this version posted September 2, 2021. The copyright holder for this preprint (which was not certified by peer review) is the author/funder, who has granted bioRxiv a license to display the preprint in perpetuity. It is made available under aCC-BY-NC 4.0 International license.

\section{Supplementary Videos}

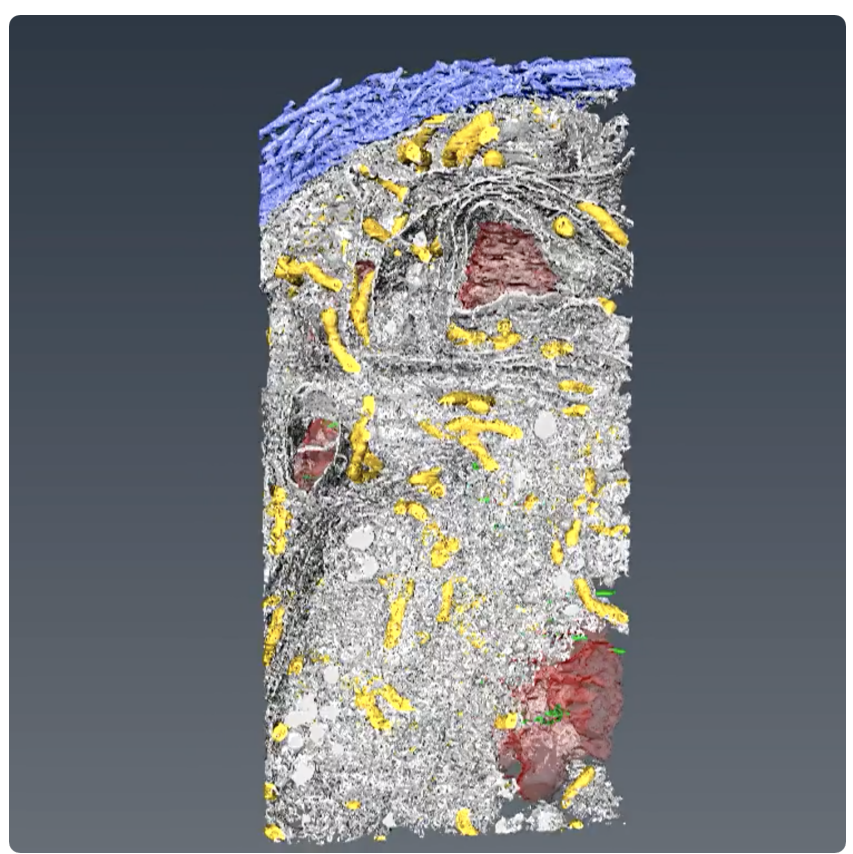

Figure SV1. 3D reconstruction of an ensheathed chromosome in a HeLa cell.

SBF-SEM data from a HeLa cell with spontaneously occurring ensheathed chromosome. The following cellular features are shown (in order of appearance: spindle microtubules (green), centrioles (yellow), DNA (red), mitochondria (multicolored then gold), endomembranes (white), plasma membrane (blue).

Figure SV2. 3D reconstruction of an ensheathed chromosome in a HeLa cell.

Same reconstruction but showing only chromosomes (red) and endomembranes (blue). Endomembranes that ensheath the chromosome of interest are shown in purple.

Figure SV3. 3D reconstruction of an ensheathed chromosome in an RPE-1 cell.

A substack from SBF-SEM imaging showing a chromosome (gray) outside the exclusion zone (pink), ensheathed in endomembranes (blue). Three complete rotations are shown with DNA only, DNA plus exclusion zone boundary, finally with endomembranes (ER and mitochrondria, brown) added. Scale bar, $2 \mu \mathrm{m}$. 
bioRxiv preprint doi: https//doi.org/10.1101/2021.04 23.441091. this version posted September 2, 2021. The copyright holder for this preprint (which was not certified by peer review) is the author/funder, who has granted bioRxiv a license to display the preprint in perpetuity. It is made available under aCC-BY-NC 4.0 International license.
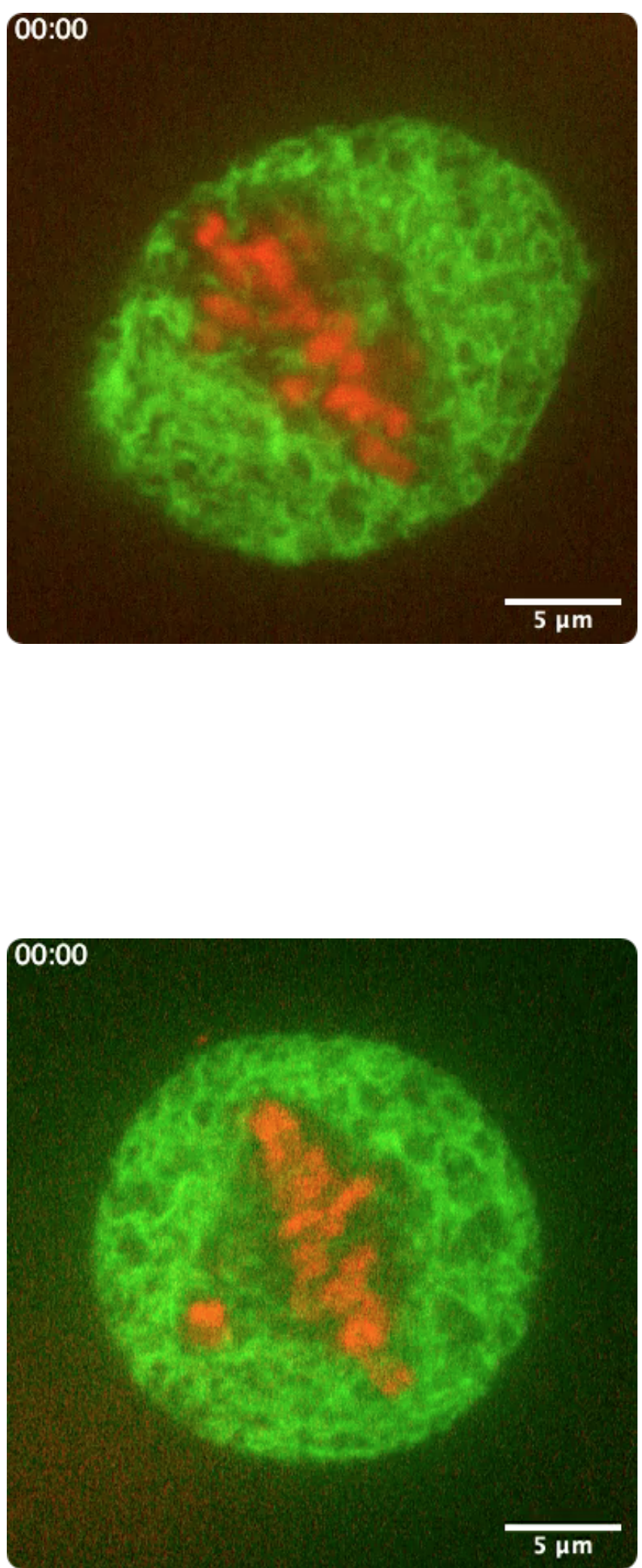

Figure SV4. Example of mitotic outcome of a cell with aligned chromosomes.

Movie of a control RPE-1 cell expressing FKBP-GFP-Sec61 $\beta$ (green) stained with SiR-DNA (red). Cell has all chromosomes aligned and divides normally. Time, hh:mm.
Figure SV5. Example of mitotic outcome of a cell with an ensheathed chromosome.

Movie of GSK923295 pre-treated RPE-1 cell expressing FKBP-GFP-Sec61 $\beta$ (green) stained with SiR-DNA (red). Cell has an ensheathed chromosome and missegregates, leading to a micronucleus. Time, hh:mm. 
bioRxiv preprint doi: https://doi.org/10.1101/2021.04.23.441091; this version posted September 2, 2021. The copyright holder for this preprint (which was not certified by peer review) is the author/funder, who has granted bioRxiv a license to display the preprint in perpetuity. It is made available under aCC-BY-NC 4.0 International license.
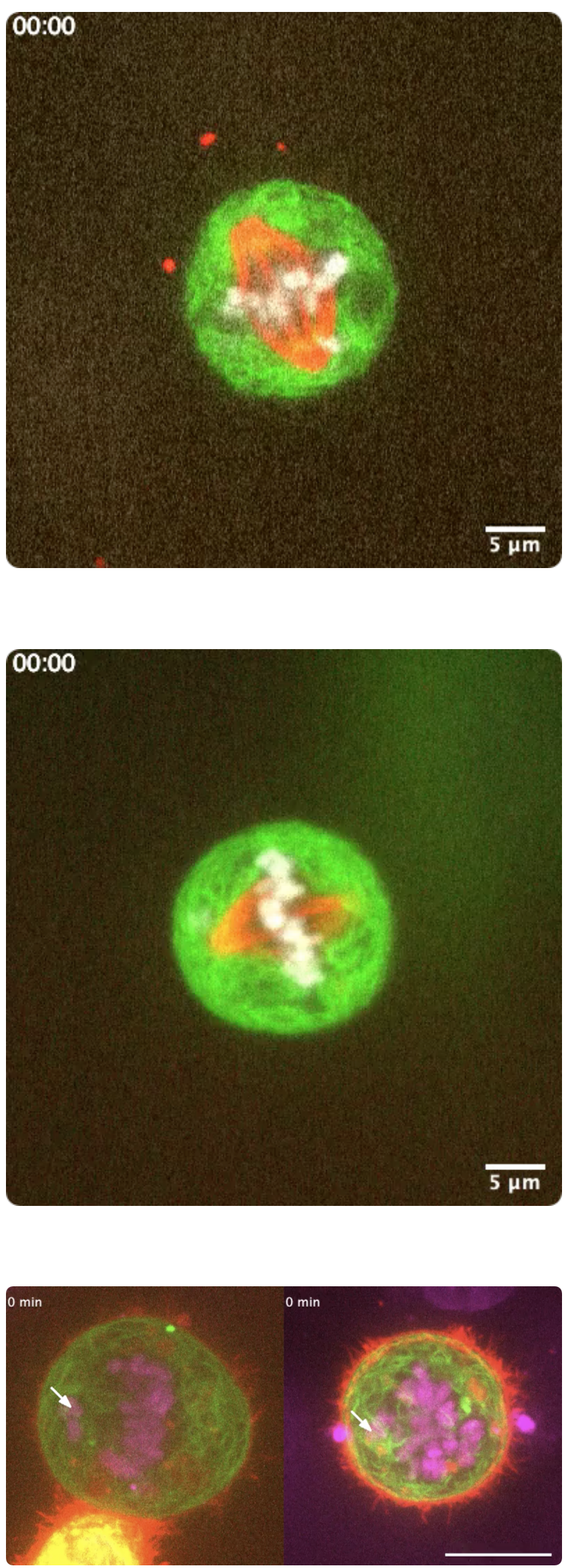

Figure SV6. Example of rescue of a misaligned chromosome.

Movies of RPE-1 cells stably expressing GFP-Sec61 $\beta$ (green) and Histone H3.2-mCherry (gray), pre-treated with GSK923295 and stained with SiR-Tubulin (red). Rescue of a misaligned chromosome is shown. Times, hh:mm.
Figure SV7. Example of missegregation of an ensheathed chromosome.

Movies of RPE-1 cells stably expressing GFP-Sec61 $\beta$ (green) and Histone H3.2-mCherry (gray), pre-treated with GSK923295 and stained with SiR-Tubulin (red). Missegregation of an ensheathed chromosome is shown. Note that the chromosome was ensheathed for $40 \mathrm{~min}$ before the movie begins. Times, hh:mm.

Figure SV8. Example of ER clearance and subsequent rescue of an ensheathed chromosome.

Movies of control (left) and ER clearance (right) in mitotic HCT116 cells expressing FKBP-GFP-Sec61 $\beta$ (green) and Stargazin-mCherry-FRB (red). DNA is stained with SiR-DNA (magenta). Scale bar, $10 \mu \mathrm{m}$. 